Article

\title{
Preliminary Structure-Activity Relationship (SAR) of a Novel Series of Pyrazole SKF-96365 Analogues as Potential Store-Operated Calcium Entry (SOCE) Inhibitors
}

\author{
Camille D. Dago ${ }^{1,2}$, Paul Le Maux ${ }^{1}$, Thierry Roisnel ${ }^{3}$ (D) , Christophe Brigaudeau $^{4,5}$, \\ Yves-Alain Bekro ${ }^{2}$, Olivier Mignen ${ }^{4,5, *(1)}$ and Jean-Pierre Bazureau ${ }^{1,6, *}$ \\ 1 Institut des Sciences Chimiques de Rennes (ISCR), UMR CNRS 6226, Groupe CORINT, \\ Université de Rennes 1 (UR1), Campus de Beaulieu, Bât. 10A, 263 Avesnue du Général Leclerc, \\ CS 74205, 35042 Rennes CEDEX, France; deliko.dago@univ-rennes1.fr (C.D.D.); \\ paul.lemaux@free.fr (P.L.M.) \\ 2 Laboratoire de Chimie Bio Organique et de Substances Naturelles (LCBOSN), \\ Université Nangui Abrogoua (UNA), Abidjan BP 802, Côte d'Ivoire; yvesalainb2014@gmail.com \\ 3 Institut des Sciences Chimiques de Rennes (ISCR), UMR CNRS 6226, Centre de Diffractométrie X (cdifx), \\ Université de Rennes 1 (UR1), Campus de Beaulieu, Bât. 10B, 263 Avenue du Général Leclerc, CS 74205, \\ 35042 Rennes CEDEX, France; thierry.roisnel@univ-rennes1.fr \\ 4 Laboratoire Canalopathies \& Signalisation Calcique, Inserm U1227, Université de Bretagne Occidentale (UBO), \\ 22 Avenue Camille Desmoulins, 29200 Brest CEDEX, France; christophe.brigaudeau@univ-brest.fr \\ 5 CalciScreen Platform, Université de Bretagne Occidentale (UBO), 22 Avenue Camille Desmoulins, \\ 29200 Brest CEDEX, France \\ 6 S2Wave Platform, ScanMAT UMS 2001 CNRS, Université de Rennes 1 (UR1), Campus de Beaulieu, Bât. 10A, \\ 263 Avenue du Général Leclerc, CS 74205, 35042 Rennes CEDEX, France \\ * Correspondence: olivier.mignen@univ-brest.fr (O.M.); jean-pierre.bazureau@univ-rennes1.fr (J.-P.B.); \\ Tel.: +33-223-236-603 (J.-P.B.)
}

Received: 15 January 2018; Accepted: 8 March 2018; Published: 14 March 2018

\begin{abstract}
From a series of $(1 R, 1 S)-1[\beta$-(phenylalkoxy)-(phenetyl)]- $1 H$-pyrazolium hydrochloride as new analogues of SKF-96365, one has an interesting effect for endoplasmic reticulum (ER) $\mathrm{Ca}^{2+}$ release and store-operated $\mathrm{Ca}^{2+}$ entry (SOCE) $\left(\mathrm{IC}_{50} 25 \mu \mathrm{M}\right)$ on the PLP-B lymphocyte cell line. A successful resolution of $( \pm)$ 1-phenyl-2-(1H-pyrazol-1-yl)ethan-1-ol has been developed by using the method of "half-concentration" in the presence of (+)-(1S)- or (-)-(1R)-CSA.
\end{abstract}

Keywords: pyrazole; SKF-96365; analogues; resolution; half-quantities; SOCE; B lymphocyte cell; SOCE inhibitor; $\mathrm{Ca}^{2+}$ signalling

\section{Introduction}

Cytoplasmic $\mathrm{Ca}^{2+}$ is very important for fundamental biological processes; this includes cell proliferation, apoptosis, migration, and gene expression [1]. The increase of cytoplasmic $\mathrm{Ca}^{2+}$ concentration following many plasma membrane receptors is connected to the release of stored $\mathrm{Ca}^{2+}$ within the endoplasmic reticulum (ER) or sarcoplasmic reticulum (SR) associated to the influx of extra-cellular $\mathrm{Ca}^{2+}$ across the plasma membrane. Store-operated $\mathrm{Ca}^{2+}$ entry (SOCE) is the typical mechanism to generate $\mathrm{Ca}^{2+}$ signals that combines the intracellular and extra-cellular processes and represents one of the most common and ubiquitous $\mathrm{Ca}^{2+}$ influx routes in non-excitable cells [2-4]. SOC entry is mediated by calcium selective channels such as the archetypal calcium-release-activated calcium (CRAC) channels in lymphocytes, which are typically supported by Orai1 proteins and regulated by STIM1 (Stromal Interacting Molecule). STIM1 is a trans-membrane protein mainly 
located in the ER membrane acting as a calcium-sensing protein, whereas Orai1 is located in the plasmalemma forming the calcium-selective pore of the CRAC channel [5]. STIM and Orai are expressed in all tissues and therefore are of first important in the numerous cellular functions. Abnormal SOC channels activities cause several human diseases, such as breast cancer [6-8], inflammatory bowel diseases [9], thrombosis [10], and severe combined immunodeficiency (SCID) disorders [11], which leads to an increasing interest in developing small molecule compounds to regulate aberrant SOC and especially CRAC channels function [12]. The therapeutic potential of inhibiting CRAC currents (named $I_{C R A C}$ ) has been established by the clinical use of calcineurin inhibitors (cyclosporine A and tacrolinus) to prevent rejection of organ transplants. Examination of literature showed that the first identified inhibitor of the CRAC channel was SKF-96365 or $1-\{\beta-[3-(4-m e t h o x y-p h e n y l)$ propoxy]-4-methoxyphenethyl\}- $1 H$-imidazole hydrochloride $[13,14]$ in 1990 (Figure 1) and is still used as a tool for the probing of receptor-mediated $\mathrm{Ca}^{2+}$ entry processes [15] in non-excitable cells [16], but it is interesting to note that the synthesis of SKF-96365 was not detailed in academic literature and also not patented. Recent studies demonstrated that it strongly inhibits voltage-gated sodium current $\left(I_{N a}\right)$ in rat ventricular myocytes using the whole-cell patch voltage-clamp technique [17]. SKF-96365 SOCE inhibitor exhibited potent anti-neoplastic activity by inducing cell-cycle arrest and apoptosis in colorectal cancer cells (HCT-116 and HT29 cells) [18]. Effect of SKF-96365 was also observed on hERG current in HEK 293 cells in a concentration-dependent manner. These blocking properties were similar to those observed previously for hERG channels by the calmodulin inhibitor W-7 [19]. All together, these results suggest a low specificity of this compound for CRAC channels.

A variety of new small molecules blocking the CRAC channels have been identified and developed, i.e., curcumin and caffeic acid phenethyl ester (CAPE) in ORAI1/STIM-co-expressing HEK 293 cells [20], 4'-[(trifluoromethyl)pyrazol-1-yl]carboxanilides exhibiting high selectivity for the CRAC channel over the voltage-operated $\mathrm{Ca}^{2+}$ (VOC) channels [21], 2-APB with a concentration-dependent effect [22], GSK-7975A by altering the Orai pore geometry [23], Synta 66 with good selectivity for CRAC channels, and no effect for $\mathrm{Ca}^{2+}$ pumps and $\mathrm{K}^{+}$channels and no interference with STIM1 aggregation [24].

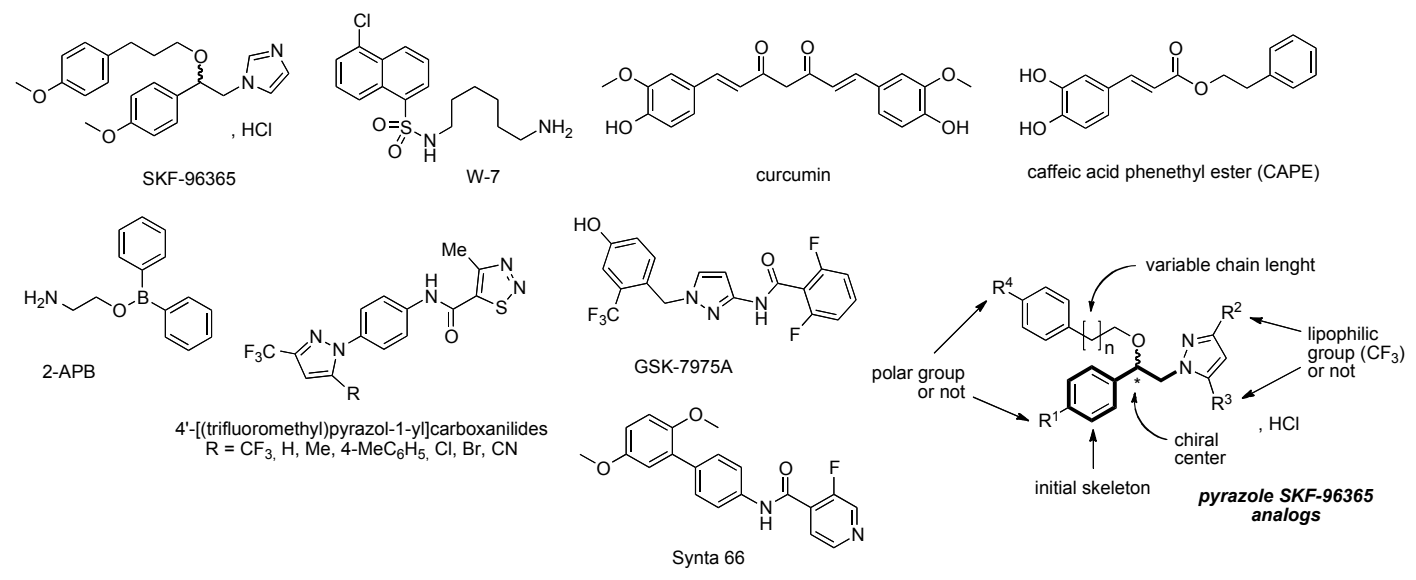

Figure 1. Structure of pharmacological inhibitors of calcium channels and structure-activity relationship (SAR) parameters of the pyrazole SKF-96365 analogues.

In this context [25], we decided to examine the synthesis of SKF-96365 analogues bearing substituted (or not) pyrazole platforms and the other parameters for this structure-activity relationship (SAR) study are respectively the length of the chain in position $C \beta$ and the presence (or not) of a methoxy polar group in para-position on the phenylethyl skeleton and on the phenylalkyloxy side chain. The generic phenylethyl skeleton is maintained for this SAR study. Effects of these analogues are also examined for endoplasmic reticulum (ER) $\mathrm{Ca}^{2+}$ release and SOCE on a B lymphocyte cell line [26]. 


\section{Results and Discussion}

\subsection{Chemistry}

These pyrazole analogues of SKF-96365 were prepared as shown in Scheme 1 using a modified method described in literature [27]. The first step involved reaction of 2-bromoacetophenone $\mathbf{1 a}$ or 2-bromo-1-(4-methoxyphenyl)ethan-1-one $\mathbf{1 b}$ with various pyrazoles $\mathbf{2}$ substituted by one or two trifluoromethyl groups (2a: pyrazole, 2b: 3-trifluoromethylpyrazole, and 2c: 3,5-bis-trifluoromethylpyrazole). The reaction was conducted with potassium carbonate in acetonitrile at room temperature. After work-up, the four desired $N$-substituted pyrazoles 3a-d were obtained in yields ranging from $53 \%$ to $69 \%$ (Table 1 ). Reduction of the ketone function of $\mathbf{3 a}-\mathbf{d}$ was realized in methanol solution at $25^{\circ} \mathrm{C}$ using sodium tetrahyborohydride during $5-7 \mathrm{~h}$. The desired hydroxyl compounds $4 \mathbf{a}-\mathbf{b}$ were obtained after elimination of volatile compounds in vacuo, and simple treatment of the crude reaction mixture with deionized water afforded $4 \mathbf{a}-\mathbf{d}$ in good yields (82-98\%) after crystallization.

Table 1. Results for the preparation of 1-phenyl-2-(1H-pyrazol-1-yl)ethan-1-one 3a-d, 1-phenyl-2-(1H-pyrazol-1-yl)ethan-1-ol $\quad 4 a-d \quad$ and $\quad( \pm)-(1 R$,

1-[ $\beta$-(phenylalkoxy)-phenethyl]-1H-pyrazolium hydrochloride $7 \mathbf{a}-\mathbf{e}$ from phenylalkyl halides $5 \mathbf{a}-\mathbf{d}$.

\begin{tabular}{|c|c|c|c|c|c|c|c|}
\hline Compound & $\mathrm{R}^{1}$ & $\mathrm{R}^{2}$ & $\mathbf{R}^{3}$ & $n$ & $\mathrm{R}^{4}$ & Yield (\%) ${ }^{a}$ & Overall Yield (\%) $b$ \\
\hline $3 a$ & $\mathrm{H}$ & $\mathrm{H}$ & $\mathrm{H}$ & - & - & 53 & - \\
\hline $3 b$ & $\mathrm{MeO}$ & $\mathrm{H}$ & $\mathrm{H}$ & - & - & 66 & - \\
\hline $3 c$ & $\mathrm{MeO}$ & $\mathrm{CF}_{3}$ & $\mathrm{H}$ & - & - & 68 & - \\
\hline $3 d$ & $\mathrm{MeO}$ & $\mathrm{CF}_{3}$ & $\mathrm{CF}_{3}$ & - & - & 69 & - \\
\hline $4 a$ & $\mathrm{H}$ & $\mathrm{H}$ & $\mathrm{H}$ & - & - & 82 & 43 \\
\hline $4 b$ & $\mathrm{MeO}$ & $\mathrm{H}$ & $\mathrm{H}$ & - & - & 86 & 57 \\
\hline $4 c$ & $\mathrm{MeO}$ & $\mathrm{CF}_{3}$ & $\mathrm{H}$ & - & - & 94 & 64 \\
\hline $4 d$ & $\mathrm{MeO}$ & $\mathrm{CF}_{3}$ & $\mathrm{CF}_{3}$ & - & - & 98 & 68 \\
\hline $7 a$ & $\mathrm{H}$ & $\mathrm{H}$ & $\mathrm{H}$ & 0 & $\mathrm{MeO}$ & 10 & 4 \\
\hline $7 \mathrm{~b}$ & $\mathrm{H}$ & $\mathrm{H}$ & $\mathrm{H}$ & 2 & $\mathrm{MeO}$ & 21 & 9 \\
\hline $7 \mathrm{c}$ & $\mathrm{MeO}$ & $\mathrm{H}$ & $\mathrm{H}$ & 0 & $\mathrm{MeO}$ & 33 & 19 \\
\hline $7 d$ & $\mathrm{MeO}$ & $\mathrm{H}$ & $\mathrm{H}$ & 2 & $\mathrm{MeO}$ & 18 & 10 \\
\hline $7 e$ & $\mathrm{MeO}$ & $\mathrm{H}$ & $\mathrm{H}$ & 2 & $\mathrm{H}$ & 33 & 17 \\
\hline $7 \mathrm{f}^{\mathrm{c}}$ & $\mathrm{H}$ & $\mathrm{H}$ & $\mathrm{H}$ & 2 & $\mathrm{H}$ & 0 & - \\
\hline $7 \mathrm{~g}^{\mathrm{d}}$ & $\mathrm{MeO}$ & $\mathrm{CF}_{3}$ & $\mathrm{H}$ & 0 & $\mathrm{MeO}$ & 0 & - \\
\hline $7 h^{\mathrm{d}}$ & $\mathrm{MeO}$ & $\mathrm{CF}_{3}$ & $\mathrm{H}$ & 2 & $\mathrm{MeO}$ & 0 & - \\
\hline $7 \mathbf{i}^{\mathrm{d}}$ & $\mathrm{MeO}$ & $\mathrm{CF}_{3}$ & $\mathrm{H}$ & 2 & $\mathrm{H}$ & 0 & - \\
\hline $7 j^{\mathrm{d}}$ & $\mathrm{MeO}$ & $\mathrm{CF}_{3}$ & $\mathrm{CF}_{3}$ & 0 & $\mathrm{MeO}$ & 0 & - \\
\hline $7 \mathbf{k}^{\mathrm{d}}$ & $\mathrm{MeO}$ & $\mathrm{CF}_{3}$ & $\mathrm{CF}_{3}$ & 2 & $\mathrm{MeO}$ & 0 & - \\
\hline $71^{d}$ & $\mathrm{MeO}$ & $\mathrm{CF}_{3}$ & $\mathrm{CF}_{3}$ & 2 & $\mathrm{H}$ & 0 & - \\
\hline
\end{tabular}

a Isolated yield after purification; ${ }^{\mathrm{b}}$ Overall yield calculated from compound $3 ;{ }^{\mathrm{c}}$ No crystallization observed after $168 \mathrm{~h} ;{ }^{\mathrm{d}}$ No crystallization after $336 \mathrm{~h}$.

In the next step, for the introduction of molecular diversity on $\mathrm{C} \beta$ hydroxyl group of 4 by $O$-alkylation, we used a series of alkyl halides 5 carrying various chains $(n=0$ or 2$)$ and methoxy group in para-position of the phenyl moiety (5a: 4-methoxybenzyl chloride; 5b: 1-(2-bromoethyl)-4-methoxybenzene; 5c: 1-(3-bromopropyl)-4-methoxybenzene; 5d: 3-phenylpropyl bromide). For optimization of the reaction condition parameters, we developed a set of experiments which are the following: (i) the choice of the solvent (DMF, DMSO, MeCN, etc.); (ii) the choice of appropriate base (DIPEA, Et $\mathrm{D}_{3} \mathrm{~N}$, $\mathrm{KOH}$ ); (iii) the number of equivalents for the base; (iv) the reaction time; and (v) appropriate reaction temperature. We obtained good reproducibility (Table 2 for each product) when we applied a reaction time of 48 or $72 \mathrm{~h}$ (monitored by thin layer chromatography on silica with appropriate eluent for evaluation of consumption of the starting reagents), 2-5 equivalents of $\mathrm{KOH}$, heating at $50{ }^{\circ} \mathrm{C}$ (during 
48 or $72 \mathrm{~h}$ ) after addition of alkyl halide 5 to produce the intermediate 6 which was not isolated (initial attempts to isolate it by flash chromatography on silica gel failed). After the addition of saturated brine to the crude reaction mixture (to solubilize the $N$-alkylated pyrazolium by-product), the intermediate 6 was extracted with dry diethyl ether and the collected extracts were directly treated with a commercial solution of $1 \mathrm{M} \mathrm{HCl}$ in ether. The desired salt 7 was collected by simple filtration after complete crystallization. It should be noted that this protocol yielded compounds $7 \mathbf{a}-\mathbf{e}$ in 10-33\% (Table 1), on the contrary, attempts to prepare the lipophilic trifluoromethyl derivatives $\mathbf{7 f}-\mathbf{l}$ failed in spite of long crystallization times (168 and $336 \mathrm{~h}$ ) at $4{ }^{\circ} \mathrm{C}$ and modification of the solvent for reaction (THF, dioxane).

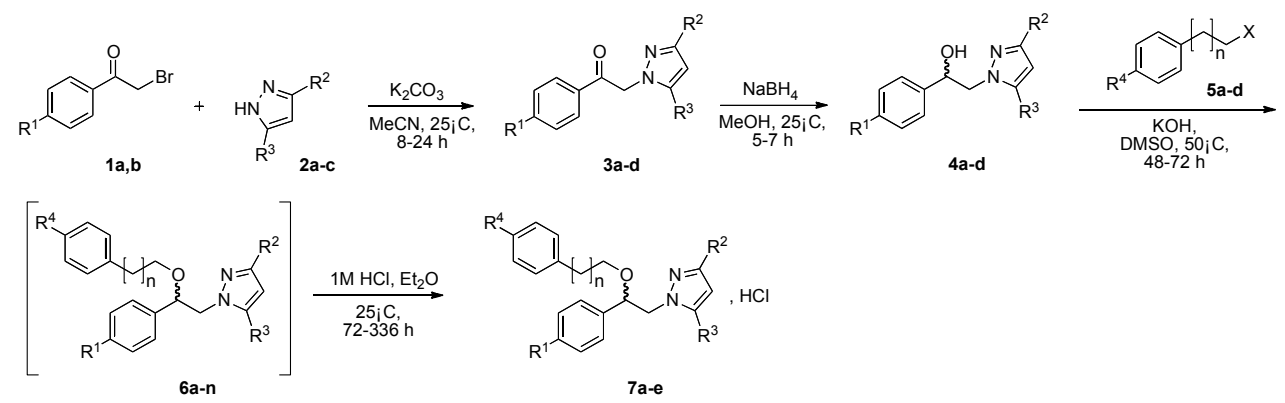

Scheme 1. Synthesis of $(1 R, 1 S)$ 1-[ $\beta$-(phenylalkoxy)-phenethyl]-1H-pyrazolium hydrochloride 7a-e.

Table 2. Optimization of the reaction conditions for the preparation of the intermediates $\mathbf{6 a}-\mathbf{n}$.

\begin{tabular}{|c|c|c|c|c|c|c|}
\hline Entry & $\begin{array}{c}\text { Starting } \\
\text { Compound } 4\end{array}$ & $\begin{array}{l}\text { Reagent } 5 \text { for } \\
O \text {-alkylation }\end{array}$ & $\begin{array}{c}\text { KOH (Number } \\
\text { of Equiv.) }\end{array}$ & $\begin{array}{l}\text { Reaction } \\
\text { Time (h) }\end{array}$ & \multicolumn{2}{|c|}{ Conversion for $6(\%)$} \\
\hline 1 & & & 2 & 48 & $6 a$ & $6^{\prime}$ \\
\hline 2 & & & 2 & 48 & $6 \mathrm{~m}$ & - \\
\hline 3 & & & 3 & 48 & $6 b$ & 76 \\
\hline 4 & & & 2 & 48 & $6 f$ & 50 \\
\hline 5 & & & 5 & 72 & $6 c$ & 68 \\
\hline 6 & $4 \mathrm{~b}$ & & 5 & 72 & $6 n$ & - \\
\hline 7 & & & 5 & 72 & $6 \mathrm{~d}$ & 43 \\
\hline 8 & & & 5 & 72 & $6 e$ & 42 \\
\hline 9 & & & 5 & 72 & $6 \mathrm{~g}$ & 86 \\
\hline 10 & & & 5 & 72 & $6 \mathrm{~h}$ & 80 \\
\hline 11 & & & 5 & 72 & $6 \mathbf{i}$ & 74 \\
\hline 12 & & & 5 & 72 & $6 j$ & 78 \\
\hline 13 & & & 5 & 72 & $6 k$ & 70 \\
\hline 14 & & & 5 & 72 & 61 & 67 \\
\hline
\end{tabular}

${ }^{a}$ Conversion determined by ${ }^{1} \mathrm{H}$ NMR in DMSO- $d_{6}$ solution after monitoring of the reaction mixture by TLC on $0.2 \mathrm{~mm}$ precoated plates of silica gel 60 F-254 (Merck KGaA, Darmstadt, Germany). 
For this structure-activity relationship (SAR) study, we were also interested to evaluate the potential impact of chirality's of the compounds 7 on SOC channels activities because our present protocol for preparation of these pyrazole SKF-96365 analogues produced a $( \pm)$ racemic mixture. Based on this finding, our attention was attracted by the method of half-quantities [28] for resolution of our $( \pm)-(1 R, 1 S)-1-(4-m e t h o x y p h e n y l)-2-(1 H$-pyrazol-1-yl)ethan-1-ol $\mathbf{4} \mathbf{b}$ mixture (Scheme 2). To find a simple and cost effective resolution procedure for (1R)- $\mathbf{4 b}$ and (1S)- $\mathbf{4 b}$, we used commercial $(+)-(1 S)$ - and $(-)-(1 R)-10$-camphorsulfonic acid (CSA). Treatment of $( \pm)-(1 R$, 1S)-1-(4-methoxyphenyl)-2-(1H-pyrazol-1-yl)ethan-1-ol $\mathbf{4 b}$ with 0.5 equivalent of $(-)-(1 R)-C S A$ in dry acetone caused the formation of a fine suspension for the first fraction of diastereomer $(-)-(1 S)-4 \mathbf{b} /(-)-(1 R)-$ CSA $(>85 \%$ de), which was recrystallized in dry acetone $(52 \%$ isolated yield, $>97 \%$ de). Then, a solution of this salt $[(-)-(1 S)-4 \mathbf{b} /(-)-(1 R)-C S A]$ in dry acetone was submitted to diasteromeric enrichment by addition of 0.02 equivalent of $( \pm)$ racemic $4 \mathbf{b}$. After work-up the pure $(-)-(1 S)-4 \mathbf{b} /(-)-(1 R)-C S A$ was obtained in $48 \%$ yield $\left(>99 \%\right.$ de) as white powder with $\left[\alpha_{D}\right]=$ $-6.0(c$ 1.0, MeOH) (Table 3). This protocol was also applied to $(+)-(1 S)-C S A$ for resolution of the $( \pm)$ racemic $4 \mathbf{b}$, and after diastereomeric enrichment, the other diastereomer $[(+)-(1 R)-4 \mathbf{b} /(+)-(1 S)-C S A$, $(>99 \%$ de) $]$ was obtained in $51 \%$ yield with $\left[\alpha_{\mathrm{D}}\right]=+6.0(c 1.0, \mathrm{MeOH})$. Crystal structures of the salt diastereomers were determined by $\mathrm{X}$-ray crystal structure analysis, as example the diastereomer $(+)-(1 R)-\mathbf{4 b} /(+)-(1 S)-C S A$ is shown in Figure 2.

Table 3. Products issued from resolution of $( \pm)-(1 R, 1 S)$ 1-(4-methoxyphenyl)-2-(1H-pyrazol-1-yl)ethan-1-ol $4 \mathbf{b}$ with (-)-(1R)-CSA and (+)-(1S)-CSA using the method of "half-quantities".

\begin{tabular}{|c|c|c|c|}
\hline Product & {$\left[\alpha_{D}\right]^{a}$} & Retention Time $t_{R}(\min .)^{b}$ & Yield (\%) \\
\hline$(-)-(1 S)-4 \mathbf{b} /(-)-(1 R)-\mathrm{CSA}$ & -6 & $34.0^{\mathrm{c}}$ & 48 \\
\hline$(+)-(1 R)-\mathbf{4 b} /(+)-(1 S)-\mathrm{CSA}$ & +6 & $31.5^{c}$ & 51 \\
\hline$(-)-(1 S)-\mathbf{4 b}$ & -10 & $52.6^{\mathrm{d}}$ & 38 \\
\hline$(+)-(1 R)-4 \mathbf{b}$ & +10 & $63.5^{\mathrm{d}}$ & 41 \\
\hline
\end{tabular}

a From: $c 1.0, \mathrm{MeOH} ;{ }^{b}$ Retention time obtained by chiral HPLC analysis using Chiracel OJ-H column $(250 \times 4.60 \mathrm{~mm})$ and UV detector at $220 \mathrm{~nm} ;{ }^{c}$ hexane $/ i-\mathrm{PrOH} 94: 6 v / v$ as eluent with flow rate $=0.8 \mathrm{~mL} / \mathrm{min}$; ${ }^{\mathrm{d}}$ hexane $/ i-\mathrm{PrOH} 96: 4$ $v / v$ as eluent with flow rate $=0.6 \mathrm{~mL} / \mathrm{min} ;{ }^{\mathrm{e}}$ Isolated yield after purification.

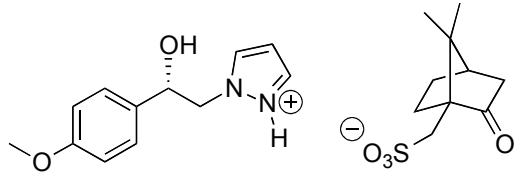

$(+)-(1 R)-\mathbf{4 b} /(+)-(1 S)-C S A$

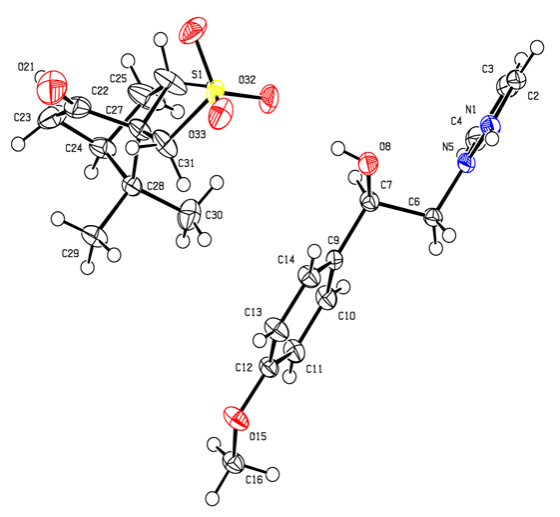

Figure 2. Ortep diagram of $(+)-(1 R)$ 1-(4-methoxyphenyl)-2-(1H-pyrazol-1-yl)ethan-1-ol 4b/(+)-(1S)-10-camphorsulfonic acid obtained by X-ray diffraction. 
Next, access to the free enantiomer (1S)-4b and (1R)-4b was operated by a simple neutralization of the respective diastereomers $(-)-(1 S)-\mathbf{4 b} /(-)-(1 R)-C S A$ or $(+)-(1 R)-4 \mathbf{b} /(+)-(1 S)-C S A$ using exactly 1 equivalent of $\mathrm{MeONa}$ in dry $\mathrm{MeOH}$. After mixing during $12 \mathrm{~h}$ followed by elimination of volatile compounds in vacuo, the crude reaction mixture was treated with deionized water and the resulting insoluble enantiomer $(-)-(1 S)-\mathbf{4 b}$ or $(+)-(1 R)-\mathbf{4 b}$ precipitated and was collected by classical filtration. As can be seen in Table 3, pure enantiomers (-)-(1S)-4b and $(+)-(1 R)-4 \mathbf{b}$ were obtained respectively in isolated yields of 38 and $41 \%$ with $\left[\alpha_{\mathrm{D}}\right]=-10.0(c 1.0, \mathrm{MeOH})$ for $(-)-(1 S)-4 \mathbf{b}(>99 \%$ ee) and $\left[\alpha_{\mathrm{D}}\right]=+10.0(c 1.0, \mathrm{MeOH})$ for $(+)-(1 R)-4 \mathbf{b}(>99 \%$ ee).

During the resolution of the $( \pm)$ racemic mixture $4 \mathbf{b}$ by the "half-quantities" protocol with $(-)-(1 R)-C S A$ or $(+)-(1 S)-C S A$ and neutralization of the two diastereomers, all these compounds were submitted to chiral HPLC analysis with a Chiracel OJ-H column $(250 \times 4.6$ i.d. $\mathrm{mm})$ and a UV detector at $220 \mathrm{~nm}$ using hexane/ $i-\mathrm{PrOH}$ as mobile phase with appropriate composition and flow rate.

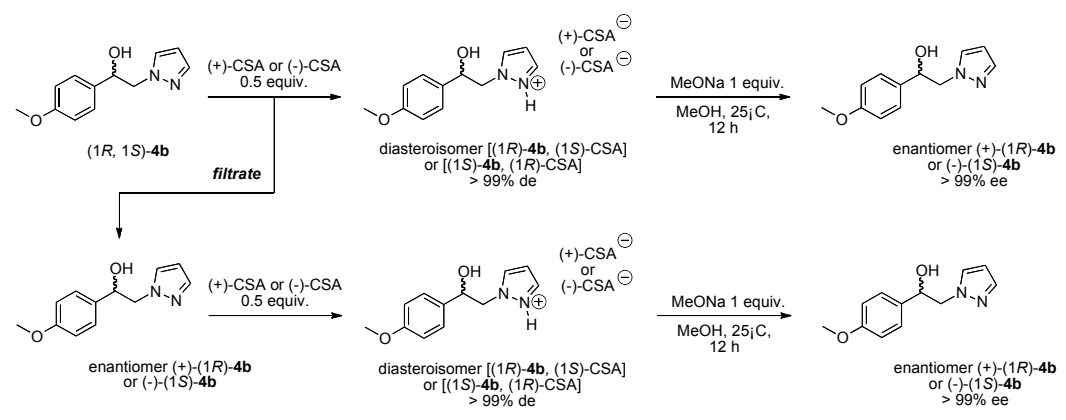

Scheme 2. Resolution of $( \pm)-(1 R, 1 S)$ 1-(4-methoxyphenyl)-2-(1H-pyrazol-1-yl)ethan-1-ol $\mathbf{4 b}$ from

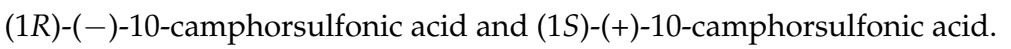

For the $( \pm)$ racemic mixture $4 \mathbf{b}$, we obtained only two peaks, the retention time of the first and second eluted enantiomers were measured respectively as 65.9 and $71.4 \mathrm{~min}$ (hexane $/ i-\mathrm{PrOH}$ $96 / 4 v / v$, flow rate $=0.6 \mathrm{~mL} / \mathrm{min}$ ). The quality of the results obtained by the "half-quantities" and neutralization methods were confirmed by the presence of only one peak for the two diastereomers $(-)-(1 S)-4 \mathbf{b} /(-)-(1 R)-C S A,(+)-(1 R)-4 \mathbf{b} /(+)-(1 S)-C S A$ and the two enantiomers $(-)-(1 S)-4 \mathbf{b}$ and $(+)-(1 R)-4 \mathbf{b}$. These data were summarized in Table 3 (the corresponding chromatograms were reported in Supplementary Materials).

With the two pure enantiomers $(-)-(1 S)-\mathbf{4 b},(+)-(1 R)-\mathbf{4} \mathbf{b}$ on hand, we were stimulated to prepare potentially the compounds $(-)-(1 S)-7 \mathbf{d}$ and $(+)-(1 R)-7 \mathbf{d}$ with the alkyl halide 1-(3-bromopropyl)-4-methoxybenzene $\mathbf{5 c}$ according to Scheme 2 . We applied the protocol used initially for the preparation of racemic $(1 R, 1 S)-7 \mathbf{d}$ using 5 equivalents of $\mathrm{KOH}$ in solution of DMSO at $50{ }^{\circ} \mathrm{C}$ during $72 \mathrm{~h}$ from (-)-(1S)-4b or (+)-(1R)-4b and 4-(3-bromopropyl)-4-methoxybenzene $\mathbf{5 c}$ (Scheme 3). Progress of the transformation and consumption of the starting reagents were monitored by ${ }^{1} \mathrm{H} N M R$ and also by thin layer chromatography on silica plates. After extraction with dry $\mathrm{Et}_{2} \mathrm{O}$ and treatment of the collected extracts with a solution of $1 \mathrm{M} \mathrm{HCl}$, to our surprise, we did not observe precipitation

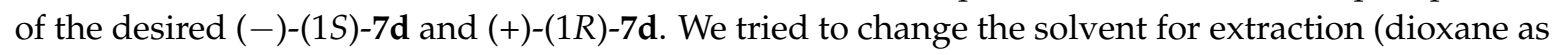
example) but this modification was not well suited for crystallization at room temperature even for an additional day at $4{ }^{\circ} \mathrm{C}$.

\subsection{Biology}

The synthesized hydrochloride compounds $7 \mathbf{a}-\mathbf{c}$ as described above were evaluated for their ability on endoplasmic reticulum (ER) $\mathrm{Ca}^{2+}$ release and SOCE using the PLP-B lymphocyte cell line. For comparison, commercial SKF-96365 hydrochloride was used as reference. All compounds 7 and SKF-96365 were added 3 min before recording intracellular $\mathrm{Ca}^{2+}$ level variation in the presence of Fura-2 dye loaded on PLP-B lymphocyte cell. Fluorescence measurements were realized in 
Flex Station ${ }^{\mathrm{TM}} 3$ microplate reader. Fura-2 loaded PLP-B lymphocyte cells were stimulated with $2 \mu \mathrm{M}$ Thapsigargin (Tg) for $30 \mathrm{~min}$ and SOCE was measured after addition of $1.8 \mathrm{mM} \mathrm{Ca}^{2+}$ in the extracellular medium. Results are respectively summarized in Table 4 and also in Figure 3A-E. For this structure-activity relationship (SAR) study, we examined mainly the effect of $\mathrm{MeO}$ substituent on the para-phenyl group of the phenethyl- $1 H$-pyrazolium skeleton and also on the phenylalkoxy chain of C $\beta$ compared to the SKF-96365 reference.

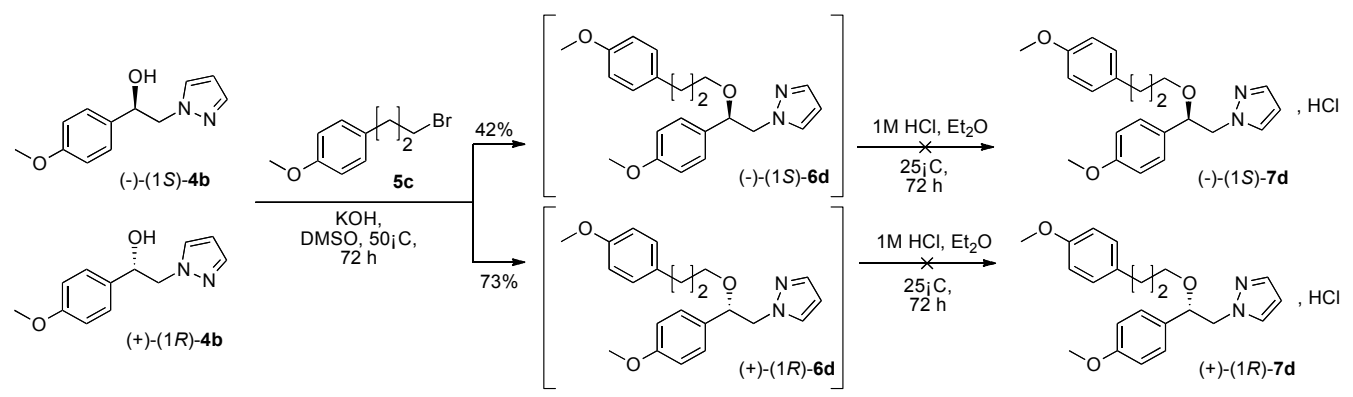

Scheme 3. Synthesis of 1-[ $\beta$-((4-methoxyphenyl)-(3-(4-methoxyphenyl)propoxyethyl)]-1H-pyrazole $(-)-(1 S)-6 \mathbf{d},(+)-(1 R)-6 \mathbf{d}$ and assays to their hydrochloride derivatives.

Examination of Table 1 and also dose response curves (Figure 3E) showed that compound $7 \mathbf{d}$ $\left(\mathrm{IC}_{50} 25 \mu \mathrm{M}\right)$ was a better potent SOCE inhibitor than SKF-96365 ( $\left.\mathrm{IC}_{50} 60 \mu \mathrm{M}\right)$. This means that a slight modification of the heterocyclic platform, particularly the position of the second nitrogen atom ( $N-3$ position in imidazole for SKF-96365 and N-2 position for $7 \mathbf{d}$ ), has a direct impact on SOCE activity. The effect of the length for the $C \beta$-(4-methoxyphenylalkoxy) side chain appeared to be important in Figure $3 \mathrm{C}$ when we compared compounds $7 \mathrm{c}$ and $7 \mathrm{~d}$ : for the same concentration of 7 , the curve obtained for compound $\mathbf{7 d}$ gave higher effect on SOCE inhibition level (\%). Again, the presence or absence of $\mathrm{MeO}$ group in para-position for the phenethyl- $1 \mathrm{H}$-pyrazolium skeleton of 7 and for the $C \beta$-phenylpropoxy side chain afforded variation of $\mathrm{IC}_{50}$, i.e., comparison of $7 \mathbf{b}\left(\mathrm{IC}_{50} 34 \mu \mathrm{M}\right)$ and $7 \mathbf{d}\left(\mathrm{IC}_{50} 25 \mu \mathrm{M}\right)$ showed that absence of $\mathrm{MeO}$ group in the skeleton of $7 \mathbf{b}$ has a lower effect on SOCE IC ${ }_{50}$. On the other hand, absence of $\mathrm{MeO}$ group of $7 \mathrm{c}\left(\mathrm{IC}_{50} 48 \mu \mathrm{M}\right)$ on the side chain led to a more important effect and the $\mathrm{IC}_{50}$ decreased. Similar observations were also made when a more physiological stimulation of SOCE activation was implemented (Figure 4). When B cells are stimulated with an antigen (M Immunoglobulin: IgM), B cell receptor (BCR) activation leads to an increase of $\mathrm{Ca}^{2+}$ concentration mainly due SOCE. However, inhibition by $7 \mathrm{c}$ and $7 \mathrm{~d}$ compounds is quite identical and less than what was observed with SKF-96365.

Here, we have reported the racemic synthesis of pyrazole SKF-96365 analogues in four steps without substituent $\left(\mathrm{CF}_{3}\right.$ group) on the pyrazole platform in moderate to good yields. For the $( \pm)$ hydroxyl intermediate 4 , we have developed a successful approach for separation of enantiomers using the method of "half-concentration" with commercial (+)-(1S)- and (-)-(1R)-10-camphorsulfonic acid (CSA) followed by neutralization of diastereomers with MeONa in dry $\mathrm{MeOH}$ solution. With the pure enantiomers $(-)-(1 S)-\mathbf{4} \mathbf{b}$ and $(+)-(1 R)-\mathbf{4} \mathbf{b}$, initial attempts to obtain the crystallized (-)-(1S)-7d and $(+)-(1 R)-7 \mathbf{d}$ after treatment of intermediate $6 \mathbf{d}$ with a solution of $1 \mathrm{M} \mathrm{HCl}$ (for precipitation of hydrochloride salt $7 \mathbf{d}$ ). Effects of compounds $7 \mathbf{a}-\mathbf{d}$ on endoplasmic reticulum (ER) $\mathrm{Ca}^{2+}$ and SOCE were evaluated on PLP-B lymphocyte cell line, and $7 \mathbf{d}$ was identified as a better SOCE inhibitor than SKF-96365. However, the inhibitory effects of $\mathbf{7 c}$ and $\mathbf{7 d}$ compounds on SOCE are inferior to what was observed for SKF-96365 when evaluated with BCR stimulation. This preliminary SAR study showed that the $\mathrm{MeO}$ group in para-position of the phenethyl- $1 \mathrm{H}$-pyrazolium skeleton or for the $C \beta$-phenylpropoxy side chain of 7 influenced the SOCE activity. These results offered possibilities to increase molecular diversity for a complete SAR study, and we are also currently exploring the potential of this synthetic methodology. 

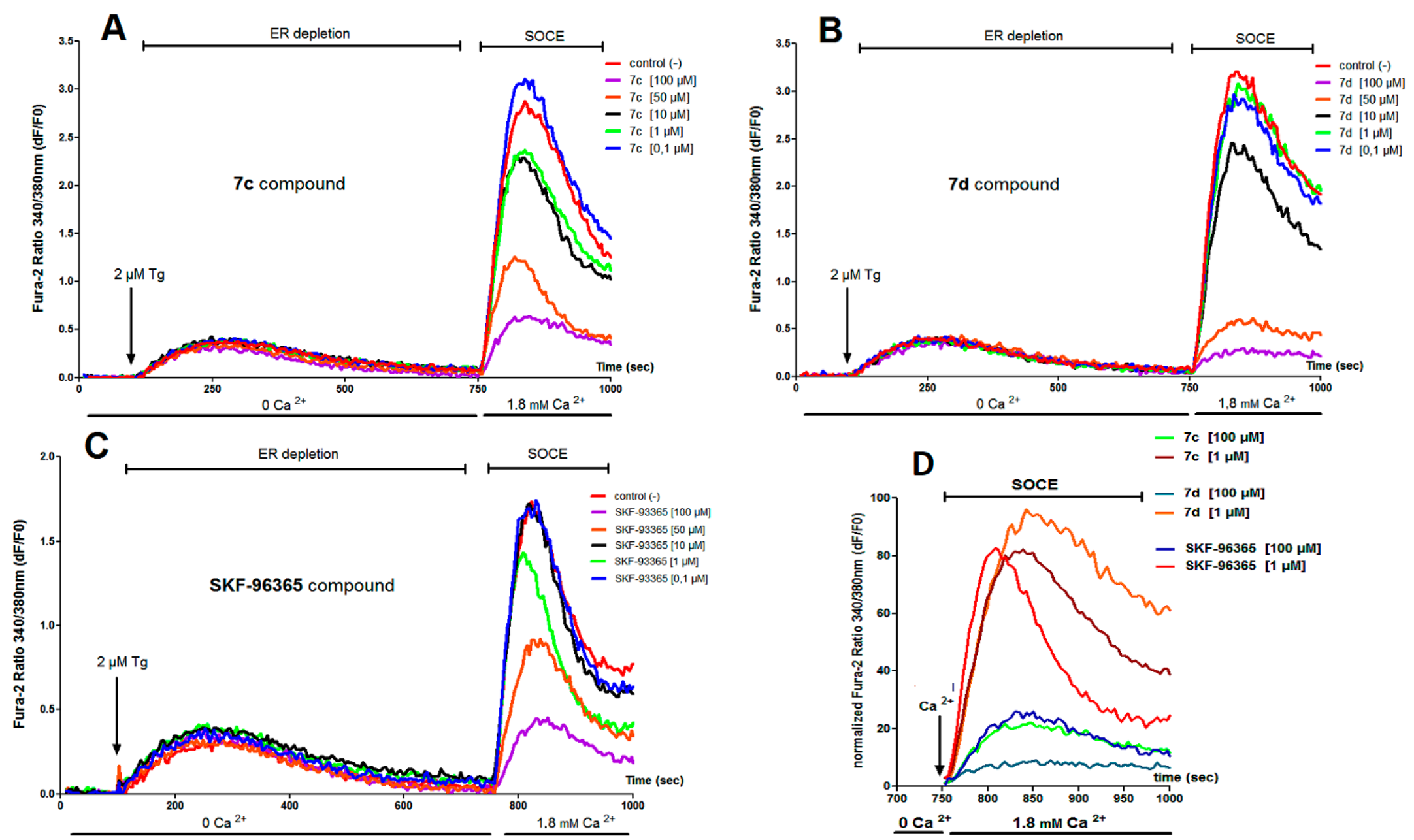

Figure 3. Cont. 


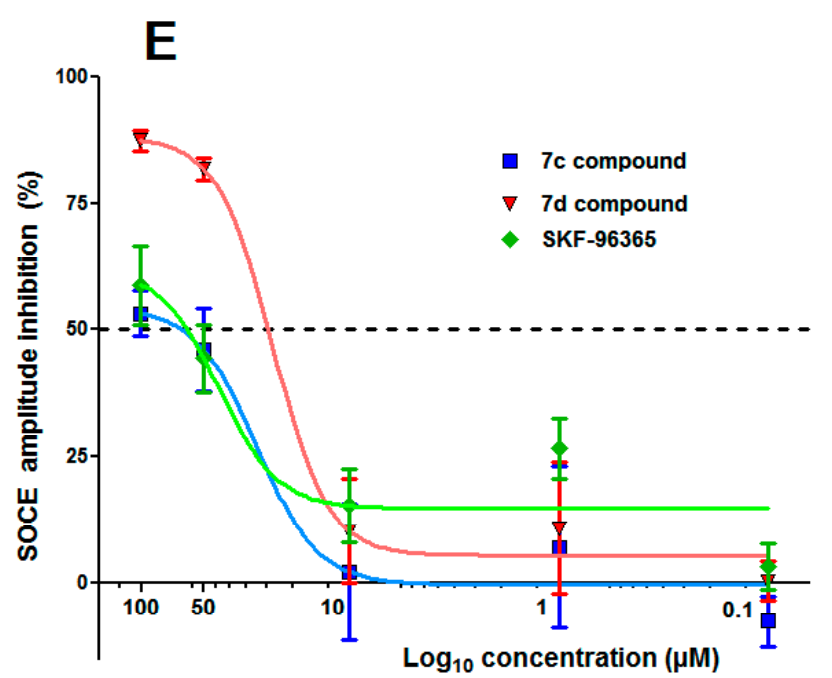

Figure 3. Effect of compounds 7c, 7d, and SKF-96365 compounds on ER Ca ${ }^{2+}$ release and store-operated $\mathrm{Ca}^{2+}$ entry (SOCE). (A-D) showed typical representative traces of intracellular $\mathrm{Ca}^{2+}$ concentration variations measured with Fura- 2 dye in PLP-B lymphocyte cell line when SOCE activation protocol is implemented. Tested compounds $7 \mathrm{c}, 7 \mathrm{~d}$, and SKF-96365 were added $3 \mathrm{~min}$ before recording intracellular $\mathrm{Ca}^{2+}$ level variation with the FlexStation $3^{\mathrm{TM}}$ plate reader. Endoplasmic reticulum (ER) $\mathrm{Ca}^{2+}$ content is first totally depleted in $\mathrm{Ca}^{2+}$ free medium by injection of $2 \mu \mathrm{M}$ Thapsigargin $\left(\mathrm{Tg}\right.$ ) and SOCE is next measured by addition of $1.8 \mathrm{mM} \mathrm{Ca}{ }^{2+}$ in the extracellular medium; (D) Representative traces of the SOCE Ca ${ }^{2+}$ signals recorded after $\mathrm{ER} \mathrm{Ca}^{2+}$ stores releases with $\mathrm{Tg}$ in cells treated with 7c, 7d, and SKF-96365 compounds $(100$ and $1 \mu \mathrm{M})$. SOCE amplitudes in the presence of the different drugs are normalized to vehicle control; (E) 7c, 7d, and SKF-936365 compounds inhibition dose-response curves: points represented the mean \pm SEM of three different experiments and expressed as the percentage of SOCE Ca ${ }^{2+}$ entry amplitude inhibition on PLP-B Lymphocyte cell line normalized to vehicle control $(100 \%)$. 
A
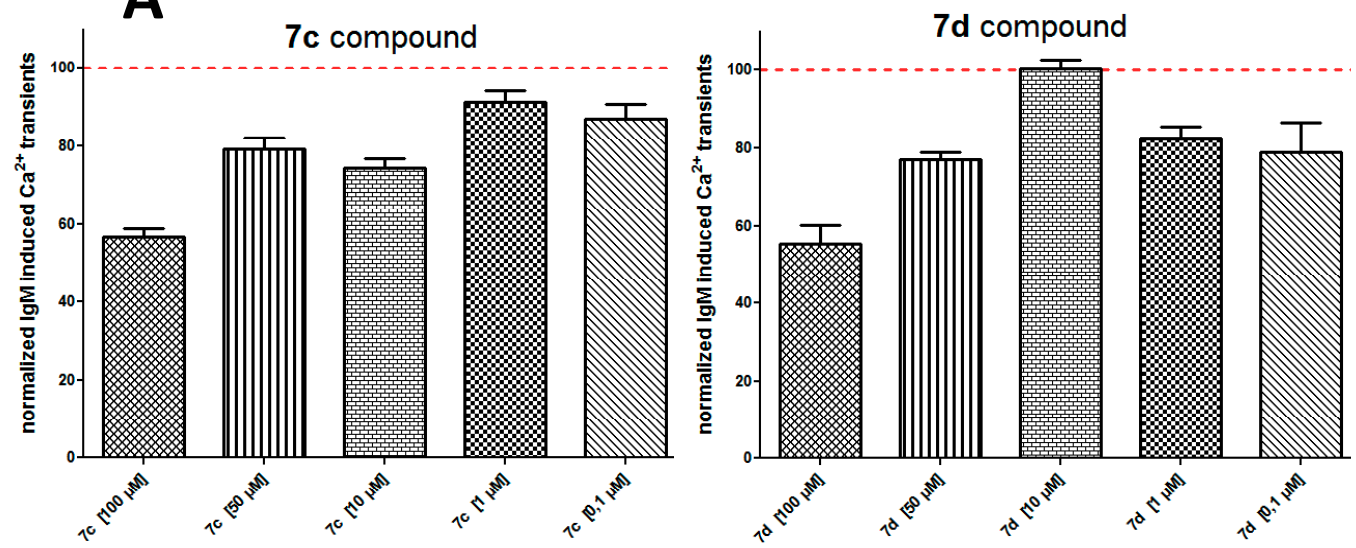

B

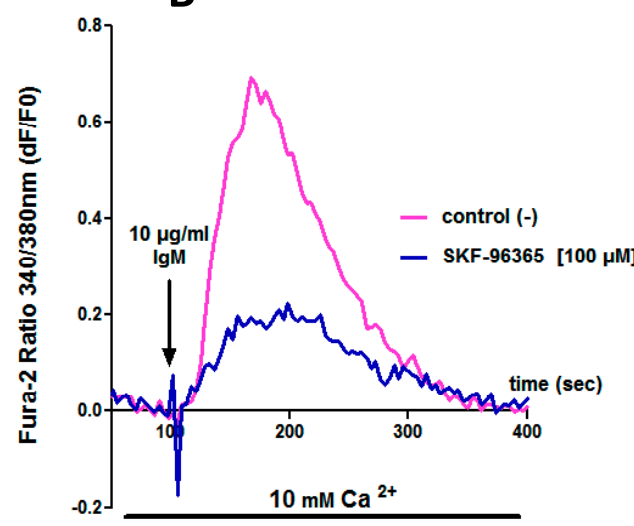

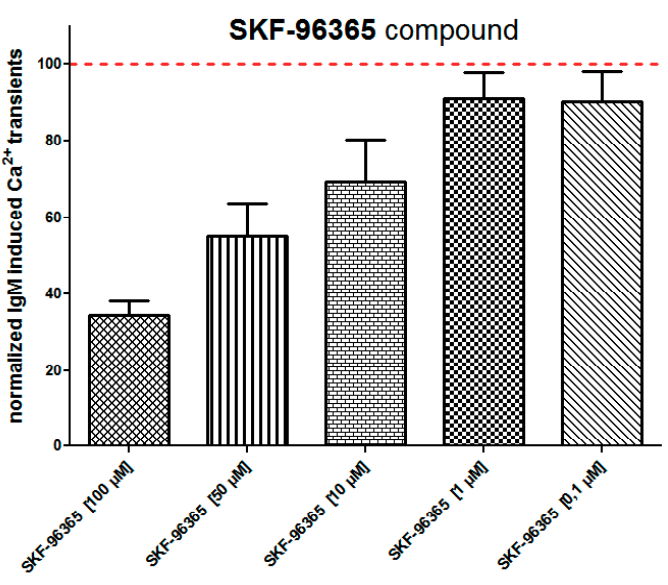

C

$-7 \mathrm{c}[100 \mu \mathrm{M}]$

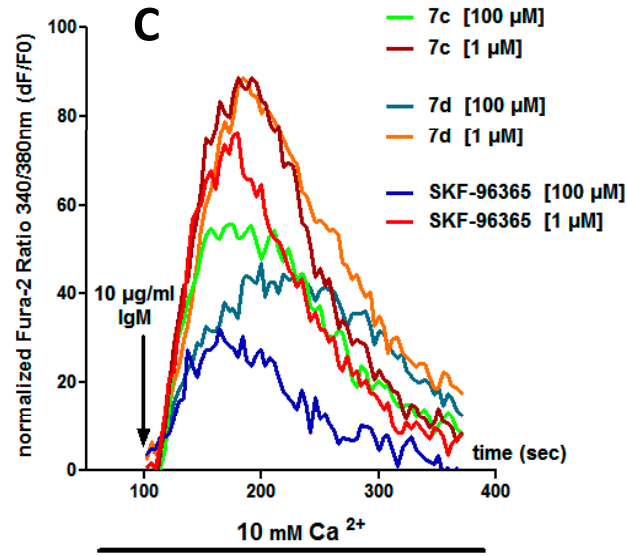

Figure 4. Effect of 7c, 7d, and SKF-96365 compounds on BCR (B Cell Receptor) induced $\mathrm{Ca}^{2+}$ responses in B cells stimulated with IgM in the presence of extracellular $\mathrm{Ca}^{2+}$. (A) histograms represent the average inhibition of IgM-induced $\mathrm{Ca}^{2+}$ transients in PLP cells treated with five different concentrations of $7 \mathrm{c}$, $7 \mathbf{d}$ and SKF-96363 compounds $(100,50,10,1$ and $0.1 \mu \mathrm{M})$. Data are normalized to vehicle control $(100 \%)$ and represented as the mean \pm SEM of 3 different experiments; (B,C) panels show typical representative traces of intracellular $\mathrm{Ca}^{2+}$ concentration variations measured with Fura-2 dye in PLP cells with BCR activation stimulation by IgM in the presence or absence of the different tested drugs. Tested compounds $7 \mathbf{c}, 7 \mathbf{d}$, and SKF-96365 were added 3 min before recording intracellular Ca ${ }^{2+}$ level variation. BCR-induced $\mathrm{Ca}^{2+}$ responses are measured in $10 \mathrm{mM} \mathrm{Ca}^{2+}$ extracellular medium in cells stimulated with $10 \mu \mathrm{g} / \mathrm{mL}$ IgM; (B) Representative traces obtained in control $(-)$ conditions or in the presence of SKF-696365 (100 $\mu \mathrm{M})$; (C) Representative traces normalized to control conditions in cells treated with 7c, 7d, and SKF-96365 compounds (100 and $1 \mu \mathrm{M})$. 
Table 4. Results for effects of $( \pm)-(1 R, 1 S)$ 1-[ $\beta$-(phenylalkoxy)-phenethyl]-1H-pyrazolium hydrochloride $7 \mathbf{a}-\mathbf{e}$ on store-operated $\mathrm{Ca}^{2+}$ entry with PLP-B lymphocyte. Store-operated $\mathrm{Ca}^{2+}$ entry was induced by depletion of Endoplasmic Reticulum $\mathrm{Ca}^{2+}$ stores (ER $\mathrm{Ca}^{2+}$ stores) with thapsigargin $(\mathrm{Tg})$ in a $\mathrm{Ca}^{2+}$-free medium and measured following the addition of $1.8 \mathrm{mM} \mathrm{CaCl}_{2}$ in the extracellular medium.

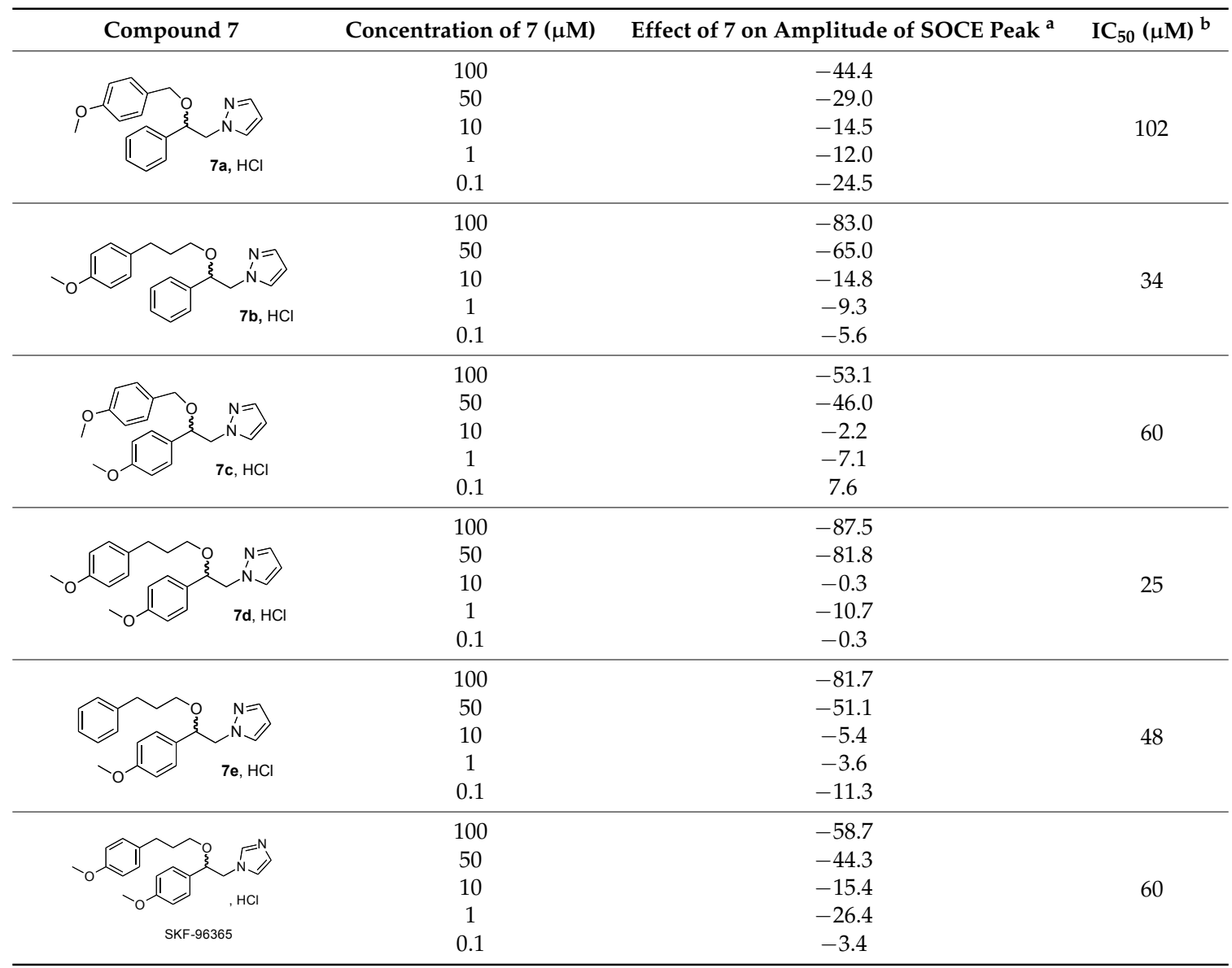

a $\%$ of inhibition (-) or activation. Controlled with DMSO $100 \%$; ${ }^{b} \mathrm{IC}_{50}$ expressed in $\mu \mathrm{M}$ are the average of three assays, $\pm 0.5 \mu \mathrm{M}$.

\section{Materials and Methods}

\subsection{Chemistry Section}

General Information. Preparative chromatography was realized on a Combi Flash $R_{f} 200 \mathrm{psi}$ UV ref. 208K20284 (Serlabo Technologies, Entraigues-sur-la-Sorgue, France) using pre-packed column of alumina gel 60 F 254 Merck equipped with a DAD UV/Vis 200-360 nm detector. Thin-layer chromatography (TLC) was accomplished on $0.2 \mathrm{~mm}$ precoated plates of silica gel 60 F-254 (Merck) with appropriate eluent. Visualization was made with ultraviolet light $(254$ and $365 \mathrm{~nm})$ or with a fluorescence indicator. Solvents were evaporated with a BUCHI rotary evaporator (New Castle, PA, USA). All reagents and solvents were purchased from Acros Fisher (Illkirch, France), Sigma-Aldrich Chimie (St. Quentin Fallavier, France), and Fluka Chimie (Paris, France) and were used without further purification. ${ }^{1} \mathrm{H}$ NMR spectra were recorded on Bruker AC $300 \mathrm{P}(300 \mathrm{MHz})$ spectrometer and ${ }^{13} \mathrm{C}$ NMR spectra on Bruker AC $300 \mathrm{P}(75 \mathrm{MHz})$ spectrometer. Chemical shifts are expressed in parts per million downfield. Data are given in the following order: $\delta$ value, multiplicity (s, singlet; $d$, doublet; $t$, triplet; q, quartet; quint: quintuplet, $\mathrm{m}$, multiplet; br, broad), number of protons, coupling constants $J$ is given in Hertz. The high-resolution mass spectra (HRMS) were recorded in positive mode using direct Electrospray infusion, respectively on Waters Q-TOF 2 or on Thermo Fisher Scientific Q-Exactive 
spectrometers at the "Centre Régional de Mesures Physiques de l'Ouest" platform (CRMPO platform, ScanMAT UMS 2001 CNRS, Rennes, France). Melting points were determined on a Kofler melting point apparatus and were uncorrected. Optical rotations $\left[\alpha_{D}\right]$ were measured on a Perkin-Elmer 214 polarimeter at room temperature $\left(25^{\circ} \mathrm{C}\right)$ and are recorded in units of $\mathrm{deg} \mathrm{cm}^{-3} \mathrm{~g}^{-1} \mathrm{dm}^{-1}(\mathrm{c}$ in $\mathrm{g} \mathrm{cm}^{-3}$ in $\mathrm{MeOH}$ ) with a $1.0 \mathrm{~cm}$ cell. The ee- and de-values were determined by chiral HPLC analysis using Chiracel OJ-H column $(250 \times 4.60 \mathrm{~mm})$ with UV detector at $220 \mathrm{~nm}$ using hexane $/ i$-PrOH as mobile phase with appropriate composition and flow rate.

1-Phenyl-2-(1H-pyrazol-1-yl)ethan-1-one (3a). To a solution of 2-bromoacetophenone 1a (4 g, $20.1 \mathrm{mmol})$ in $20.8 \mathrm{~mL}$ of acetonitrile, pyrazole $2 \mathrm{a}(1.45 \mathrm{~g}, 21.3 \mathrm{mmol}, 1.06$ equiv.) was added in small portions under vigorous magnetic stirring (550 rpm) at room temperature, and mixing was pursued until complete dissolution of the reagents. To this homogeneous solution, $\mathrm{K}_{2} \mathrm{CO}_{3}(2.92 \mathrm{~g}, 21.1 \mathrm{mmol}$, 1.05 equiv.) was poured and the resulting suspension was stirred for $8 \mathrm{~h}$ at $25^{\circ} \mathrm{C}$ and monitored by thin layer chromatography on $0.2 \mathrm{~mm}$ plates of silica gel $60 \mathrm{~F}-254$ (Merck) using cyclohexane/ AcOEt $(1: 1 v / v)$ as eluent. The reaction mixture was diluted with $20 \mathrm{~mL}$ of AcOEt, and the resulting solution was filtered on a Büchner funnel (porosity $\mathrm{N}^{\circ} 4$ ) and the residual precipitate was washed with AcOEt $(2 \times 10 \mathrm{~mL})$. The collected filtrate was transferred into a separating funnel. The organic phase was washed successively with deionized water $(3 \times 80 \mathrm{~mL})$, brine $(3 \times 80 \mathrm{~mL})$, and dried over magnesium sulfate. After filtration on a filter paper, the filtrate was concentrated in a rotary evaporator under reduced pressure and the oily residue was submitted to purification by preparative chromatography (Combi Flash $R_{f} 200$ psi apparatus with a DAD 200/360 nm detector) on pre-packed column of silica gel 60 F-254 (Merck) using a stepwise gradient of cyclohexane/ AcOEt (0-50\%) for elution. Pooling for $60 \mathrm{~min}$ and elimination of the solvent in vacuo gave $3.74 \mathrm{~g}$ (53\% yield) of the pure desired compound 3a as yellowish powder. $\mathrm{Mp}=96-97{ }^{\circ} \mathrm{C} .{ }^{1} \mathrm{H}$ NMR (DMSO- $\left.d_{6}\right) \delta=5.84\left(\mathrm{~s}, 2 \mathrm{H}, \mathrm{CH}_{2}, \mathrm{H}-2\right), 6.31$ (dd, $\left.J=2.3,1.9 \mathrm{~Hz}, 1 \mathrm{H}, \mathrm{H}-4^{\prime}\right), 7.48\left(\mathrm{dd}, 1 \mathrm{H}, J=1.9,0.7 \mathrm{~Hz}, \mathrm{H}-3^{\prime}\right), 7.52-7.63\left(\mathrm{~m}, 2 \mathrm{H}, \mathrm{H}-3^{\prime \prime}, \mathrm{H}-5^{\prime \prime}, \mathrm{Ar}\right), 7.66-7.77$ (m, 2H, H-4" $\left., \mathrm{H}-5^{\prime}, \mathrm{Ar}\right), 7.97-8.09$ (m, 2H, H-2", $\left.\mathrm{H}-6^{\prime \prime}\right) .{ }^{13} \mathrm{C}$ NMR (DMSO- $\left.d_{6}\right) \delta=57.7$ (C-2), $105.6\left(\mathrm{C}-4^{\prime}\right)$, 128.1 (C-3", C-5"), 129.0 (C-2", C-6"), 131.6 (C-5'), 134.0 (C-4"), 134.6 (C-1"), 139.0 (C-3'), 193.7 (C=O). ES $^{+}$HRMS, $m / z=209.0689$ found (calculated for $\mathrm{C}_{11} \mathrm{H}_{10} \mathrm{~N}_{2} \mathrm{ONa}[\mathrm{M}+\mathrm{Na}]^{+}$requires 209.0691).

1-(4-Methoxyphenyl)-2-(1H-pyrazol-1-yl)ethan-1-one (3b). $\quad$ To a solution of 2-bromo-1-(4-methoxyphenyl)ethan-1-one $\mathbf{1 b}(4.6 \mathrm{~g}, 20.1 \mathrm{mmol})$ in $20.8 \mathrm{~mL}$ of acetonitrile, pyrazole 2a (2.74 g, $40.2 \mathrm{mmol}$, 2 equiv.) was added in small portions under vigorous magnetic stirring (550 rpm) at room temperature, and mixing was pursued until complete dissolution of the reagents. To this homogeneous solution, $\mathrm{K}_{2} \mathrm{CO}_{3}(5.56 \mathrm{~g}$, $40.2 \mathrm{mmol}$, 2 equiv.) was poured and the resulting suspension was stirred for $12 \mathrm{~h}$ at $25^{\circ} \mathrm{C}$ and monitored by thin layer chromatography on $0.2 \mathrm{~mm}$ plates of silica gel $60 \mathrm{~F}-254$ (Merck) using cyclohexane/AcOEt (3:7 v/v) as eluent. The reaction mixture was diluted with $20 \mathrm{~mL}$ of AcOEt, and the resulting suspension was filtered on a Büchner funnel (porosity $\left.\mathrm{N}^{\circ} 4\right)$ and the residual precipitate was washed with AcOEt $(2 \times 10 \mathrm{~mL})$. The collected filtrate was transferred into a separating funnel. The organic phase was washed successively with deionized water $(3 \times 80 \mathrm{~mL})$, brine $(3 \times 80 \mathrm{~mL})$, and dried over magnesium sulfate. After filtration on a filter paper, the filtrate was concentrated in a rotary evaporator under reduced pressure and the oily residue was submitted to purification by preparative chromatography (Combi Flash $R_{f} 200 \mathrm{psi}$ apparatus with a DAD 200/360 nm detector) on pre-packed column of silica gel 60 F-254 (Merck) using a stepwise gradient of cyclohexane/AcOEt (0-70\%) for elution. Pooling for $60 \mathrm{~min}$ and elimination of the solvent in vacuo gave $4.35 \mathrm{~g}$ ( $66 \%$ yield) of the pure desired compound $3 \mathbf{b}$ as yellowish needles. $\mathrm{Mp}=102-103{ }^{\circ} \mathrm{C} .{ }^{1} \mathrm{H}$ NMR $\left(\mathrm{DMSO}-d_{6}\right) \delta=3.86\left(\mathrm{~s}, 3 \mathrm{H}, \mathrm{OCH}_{3}\right), 5.77\left(\mathrm{~s}, 2 \mathrm{H}, \mathrm{CH}_{2}, \mathrm{H}-2\right), 6.30(\mathrm{t}, 1 \mathrm{H}$, $\left.J=2.1 \mathrm{~Hz}, \mathrm{H}-4^{\prime}\right), 7.09\left(\mathrm{~d}, 2 \mathrm{H}, J=8.9 \mathrm{~Hz}, \mathrm{H}-3^{\prime \prime}, \mathrm{H}-5^{\prime \prime}, \mathrm{Ar}\right), 7.47\left(\mathrm{dd}, 1 \mathrm{H}, J=1.9,0.7 \mathrm{~Hz}, \mathrm{H}-3^{\prime}\right), 7.72(\mathrm{dd}$, $\left.1 \mathrm{H}, J=2.3,0.7 \mathrm{~Hz}, \mathrm{H}-5^{\prime}\right), 8.01\left(\mathrm{~d}, 2 \mathrm{H}, J=8.9 \mathrm{~Hz}, \mathrm{H}-2^{\prime \prime}, \mathrm{H}-6^{\prime \prime}, \mathrm{Ar}\right) .{ }^{13} \mathrm{C} \mathrm{NMR}\left(\mathrm{DMSO}-d_{6}\right) \delta=55.7\left(\mathrm{OCH}_{3}\right)$, 57.3 (C-2), $105.5\left(\mathrm{C}-4^{\prime}\right), 114.2\left(\mathrm{C}-3^{\prime \prime}, \mathrm{C}-5^{\prime \prime}\right), 127.4\left(\mathrm{C}-5^{\prime}\right), 130.4\left(\mathrm{C}-2^{\prime \prime}, \mathrm{C}-6^{\prime \prime}\right), 131.6\left(\mathrm{C}-1^{\prime \prime}\right), 138.8\left(\mathrm{C}-3^{\prime}\right)$, $163.6\left(\mathrm{C}-4^{\prime \prime}\right), 191.9(\mathrm{C}=\mathrm{O})$. $\mathrm{ES}^{+}$HRMS, $m / z=239.0798$ found (calculated for $\mathrm{C}_{12} \mathrm{H}_{12} \mathrm{~N}_{2} \mathrm{O}_{2} \mathrm{Na}[\mathrm{M}+\mathrm{Na}]^{+}$ requires 239.0797). 
2-(3-Trifluoromethyl-1H-pyrazol-1-yl)-1-(4-methoxyphenyl)ethan-1-one (3c). $\quad$ To a solution of 2-bromo-1-(4-methoxyphenyl)ethan-1-one $1 \mathrm{~b}(0.5 \mathrm{~g}, 2.18 \mathrm{mmol})$ in $2.25 \mathrm{~mL}$ of acetonitrile, 3-trifluoromethylpyrazole $\mathbf{2 b}(0.89 \mathrm{~g}, 6.54 \mathrm{mmol}, 3$ equiv.) was added in small portions under vigorous magnetic stirring (550 rpm) at room temperature, and mixing was pursued until complete dissolution of the reagents. To this homogeneous solution, $\mathrm{K}_{2} \mathrm{CO}_{3}(0.905 \mathrm{~g}, 6.54 \mathrm{mmol}, 3$ equiv. $)$ was poured and the resulting suspension was stirred for $12 \mathrm{~h}$ at $25^{\circ} \mathrm{C}$ and monitored by thin layer chromatography on $0.2 \mathrm{~mm}$ plates of silica gel 60 F-254 (Merck) using cyclohexane/AcOEt (1:1 $v / v)$ as eluent. The reaction mixture was diluted with $5 \mathrm{~mL}$ of $\mathrm{AcOEt}$, and the resulting solution was filtered on a Büchner funnel (porosity $\mathrm{N}^{\circ} 4$ ) and the residual precipitate was washed with $5 \mathrm{~mL}$ of AcOEt. The collected filtrate was transferred into a separating funnel. The organic phase was washed successively with deionized water $(3 \times 20 \mathrm{~mL})$, brine $(3 \times 20 \mathrm{~mL})$, and dried over magnesium sulfate. After filtration on a filter paper, the filtrate was concentrated in a rotary evaporator under reduced pressure and gave a solid residue. After addition of $40 \mathrm{~mL}$ of hexane and mixing for $4 \mathrm{~h}$, the solid was filtered on a Büchner funnel (porosity $\mathrm{N}^{\circ} 4$ ) then dried at $60^{\circ} \mathrm{C}$ for $3 \mathrm{~h}$ and gave $0.62 \mathrm{~g}$ ( $68 \%$ yield) of the desired compound $3 \mathrm{c}$ as white powder. $\mathrm{Mp}=146-147^{\circ} \mathrm{C} .{ }^{1} \mathrm{H}$ NMR (DMSO- $\left.d_{6}\right) \delta=3.87\left(\mathrm{~s}, 3 \mathrm{H}, \mathrm{OCH}_{3}\right), 5.94\left(\mathrm{~s}, 2 \mathrm{H}, \mathrm{CH}_{2}\right.$, $\mathrm{H}-2), 6.78\left(\mathrm{dd}, 1 \mathrm{H}, J=2.4,0.7 \mathrm{~Hz}, \mathrm{H}-4^{\prime}, \mathrm{Ar}\right), 7.12$ (d, 2H, $\left.J=8.9 \mathrm{~Hz}, \mathrm{H}-3^{\prime \prime}, \mathrm{H}-5^{\prime \prime}, \mathrm{Ar}\right), 7.95$ (dq, 1H, $\left.J=2.1,1.0 \mathrm{~Hz}, \mathrm{H}-5^{\prime}, \mathrm{Ar}\right), 8.02\left(\mathrm{~d}, 2 \mathrm{H}, J=8.9 \mathrm{~Hz}, \mathrm{H}-2^{\prime \prime}, \mathrm{H}-6{ }^{\prime \prime}, \mathrm{Ar}\right) .{ }^{13} \mathrm{C} \mathrm{NMR}\left(\mathrm{DMSO}-d_{6}\right) \delta=55.8\left(\mathrm{OCH}_{3}\right)$, 58.1 (C-2), $104.4\left(\mathrm{C}-4^{\prime}\right), 104.4$ (C-4'), 114.2 (C-2", C-6"), 114.3 (C-2", C-6"), 127.1 (C-1"), 130.4 (C-3",

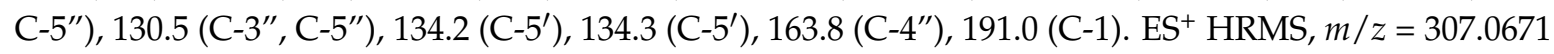
found (calculated for $\mathrm{C}_{13} \mathrm{H}_{11} \mathrm{~N}_{2} \mathrm{O}_{2} \mathrm{~F}_{3} \mathrm{Na}[\mathrm{M}+\mathrm{Na}]^{+}$requires 307.0670); 285.0862 found (calculated for $\mathrm{C}_{13} \mathrm{H}_{12} \mathrm{~N}_{2} \mathrm{O}_{2} \mathrm{~F}_{3}[\mathrm{M}+\mathrm{H}]^{+}$requires 285.0851).

2-(3,5-Bis-trifluoromethyl-1H-pyrazol-1-yl)-1-(4-methoxyphenyl)ethan-1-one (3d). To a solution of 2-bromo-1-(4-methoxyphenyl)ethan-1-one $1 \mathbf{b}(0.5 \mathrm{~g}, 2.18 \mathrm{mmol})$ in $2.25 \mathrm{~mL}$ of acetonitrile, 3,5-bis-trifluoromethylpyrazole $2 \mathrm{c}(1.778 \mathrm{~g}, 8.72 \mathrm{mmol}, 4$ equiv.) was added in small portions under vigorous magnetic stirring (550 rpm) at room temperature, and mixing was pursued until complete dissolution of the reagents. To this homogeneous solution, $\mathrm{K}_{2} \mathrm{CO}_{3}(1.205 \mathrm{~g}, 8.72 \mathrm{mmol}, 4$ equiv.) was poured and the resulting suspension was stirred for $24 \mathrm{~h}$ at $25{ }^{\circ} \mathrm{C}$ and monitored by thin layer chromatography on $0.2 \mathrm{~mm}$ plates of silica gel $60 \mathrm{~F}-254$ (Merck) using cyclohexane/AcOEt $(1: 1 \mathrm{v} / \mathrm{v})$ as eluent. The reaction mixture was diluted with $5 \mathrm{~mL}$ of AcOEt, and the resulting solution was filtered on a Büchner funnel (porosity $\mathrm{N}^{\circ} 4$ ) and the residual precipitate was washed with $5 \mathrm{~mL}$ of AcOEt. The collected filtrate was transferred into a separating funnel. The organic phase was washed successively with deionized water $(3 \times 20 \mathrm{~mL})$, brine $(3 \times 20 \mathrm{~mL})$, and dried over magnesium sulfate. After filtration on a filter paper, the filtrate was concentrated in a rotary evaporator under reduced pressure and gave a solid residue which was dried under high vacuum $\left(10^{-2}\right.$ Torr $)$ at $25^{\circ} \mathrm{C}$ for $2 \mathrm{~h}$. The desired compound $3 \mathrm{~d}$ was obtained in $69 \%$ yield as white powder. $\mathrm{Mp}=114-115^{\circ} \mathrm{C} .{ }^{1} \mathrm{H} \mathrm{NMR}$ $\left(\right.$ DMSO- $\left._{6}\right) \delta=3.88\left(\mathrm{~s}, 3 \mathrm{H}, \mathrm{OCH}_{3}\right), 6.19\left(\mathrm{~s}, 2 \mathrm{H}, \mathrm{CH}_{2}, \mathrm{H}-2\right), 7.12\left(\mathrm{~d}, 2 \mathrm{H}, J=8.9 \mathrm{~Hz}, \mathrm{H}-3^{\prime \prime}, \mathrm{H}-5^{\prime \prime}, \mathrm{Ar}\right)$, $7.69\left(\mathrm{~s}, 1 \mathrm{H}, \mathrm{H}-4^{\prime}, \mathrm{Ar}\right), 8.05\left(\mathrm{~d}, 1 \mathrm{H}, J=8.9 \mathrm{~Hz}, \mathrm{H}-2^{\prime \prime}, \mathrm{H}-6{ }^{\prime \prime}, \mathrm{Ar}\right) .{ }^{13} \mathrm{C}$ NMR $\left(\mathrm{DMSO}-d_{6}\right) \delta=55.8\left(\mathrm{OCH}_{3}\right)$, 58.5 (C-2), $107.5\left(\mathrm{C}-4^{\prime}\right), 114.3$ (C-3", C-5"), 126.3 (C-1"), 130.8 (C-2", C-6"), 164.2 (C-4"), 189.9 (C=O). ES HRMS, $m / z=375.0544$ found (calculated for $\mathrm{C}_{14} \mathrm{H}_{10} \mathrm{~N}_{2} \mathrm{O}_{2} \mathrm{~F}_{6} \mathrm{Na}[\mathrm{M}+\mathrm{Na}]^{+}$requires 375.0544); 353.0734 found (calculated for $\mathrm{C}_{14} \mathrm{H}_{11} \mathrm{~N}_{2} \mathrm{O}_{2} \mathrm{~F}_{3}[\mathrm{M}+\mathrm{H}]^{+}$requires 353.0734).

3.1.1. General Procedure for Reduction of 1-Phenyl-2-(1H-pyrazol-1-yl)ethan-1-one (3a-c) into 1-Phenyl-2-(1H-pyrazol-1-yl)ethan-1-ol (4a-c)

To a solution of 1-phenyl-2-(1H-pyrazol-1-yl)ethan-1-one $3(5 \mathrm{mmol})$ in an appropriate volume of anhydrous methanol (9-40 mL), sodium borohydride $\mathrm{NaBH}_{4}(0.189 \mathrm{~g}, 5 \mathrm{mmol}, 1$ equiv.) was added in small portions at $0{ }^{\circ} \mathrm{C}$ (ice bath) under magnetic stirring $(300 \mathrm{rpm}$ ). The resulting mixture was stirred $(500 \mathrm{rpm})$ for an appropriate reaction time $(5-7 \mathrm{~h})$ at room temperature, and the reaction solution was monitored by thin layer chromatography (TLC) on $0.2 \mathrm{~mm}$ plates of silica gel 60 F-254 (Merck) using an appropriate mixture of solvents as eluent. The reaction mixture was concentrated in a rotary evaporator under reduced pressure and the resulting solid residue was washed with deionized water 
$(3 \times 45-3 \times 47 \mathrm{~mL})$ on a Büchner funnel. Then, the desired compounds $3 \mathbf{a}-\mathbf{c}$ were dried at $60{ }^{\circ} \mathrm{C}$ for $3 \mathrm{~h}$.

1-Phenyl-2-(1H-pyrazol-1-yl)ethan-1-ol (4a). According to the standard procedure, the compound 4a was prepared from 1-phenyl-2-(1H-pyrazol-1-yl)ethan-1-one $3 \mathbf{a}(0.93 \mathrm{~g}, 5 \mathrm{mmol})$ in $9.3 \mathrm{~mL}$ of anhydrous methanol after a reaction time of $5 \mathrm{~h}$ using $\mathrm{CH}_{2} \mathrm{Cl}_{2} / \mathrm{MeOH}$ 9:1 $v / v$ as eluent for thin layer chromatography. Washing work-up was realized with $3 \times 45 \mathrm{~mL}$ of deionized water and gave 0.94 $\mathrm{g}(82 \%$ yield $)$ of the desired compound $4 \mathrm{a}$ as white powder. $\mathrm{Mp}=132-134{ }^{\circ} \mathrm{C} .{ }^{1} \mathrm{H}$ NMR $\left(\mathrm{DMSO}-d_{6}\right)$ $\delta=4.14-4.30\left(\mathrm{~m}, 2 \mathrm{H}, \mathrm{CH}_{2}, \mathrm{H}-2\right), 4.83-5.01(\mathrm{~m}, 1 \mathrm{H}, \mathrm{CH}, \mathrm{H}-1), 5.65(\mathrm{br} \mathrm{d}, 1 \mathrm{H}, J=4.7 \mathrm{~Hz}, \mathrm{OH}), 6.18(\mathrm{t}$, $\left.1 \mathrm{H}, J=2.0 \mathrm{~Hz}, \mathrm{H}-4^{\prime}\right), 7.19-7.39$ (m, 5H, H-2", H-3", H-4", H-5", $\left.\mathrm{H}-6^{\prime \prime}, \mathrm{Ar}\right), 7.43$ (dd, 1H, J = 1.9, $0.7 \mathrm{~Hz}$, $\left.\mathrm{H}-3^{\prime}\right), 7.58\left(\mathrm{dd}, 1 \mathrm{H}, J=2.3,0.7 \mathrm{~Hz}, \mathrm{H}-5^{\prime}\right) .{ }^{13} \mathrm{C}$ NMR (DMSO- $\left.d_{6}\right) \delta=58.7$ (C-2), $71.8(\mathrm{C}-1), 104.7\left(\mathrm{C}-4^{\prime}\right)$, 126.1 (C-3", C-5"), 127.4 (C-4"), 128.2 (C-2", C-6"), 130.7 (C-5'), 138.5 (C-1"), 142.8 (C-3'). ES ${ }^{+}$HRMS, $m / z=211.0848$ found (calculated for $\mathrm{C}_{11} \mathrm{H}_{12} \mathrm{~N}_{2} \mathrm{O}_{2} \mathrm{Na}[\mathrm{M}+\mathrm{Na}]^{+}$requires 211.0847).

1-(4-Methoxyphenyl)-2-(1H-pyrazol-1-yl)ethan-1-ol (4b). According to the standard procedure, the compound $\mathbf{4 b}$ was prepared from 1-(4-methoxyphenyl)-2-(1H-pyrazol-1-yl)ethan-1-one $\mathbf{3 b}$ (1.08 $\mathrm{g}$, $5 \mathrm{mmol}$ ) in $14.4 \mathrm{~mL}$ of anhydrous methanol after a reaction time of $7 \mathrm{~h}$ using $\mathrm{CH}_{2} \mathrm{Cl}_{2} / \mathrm{MeOH}$ 8:2 $v / v$ as eluent for thin layer chromatography. Washing work-up was realized with $3 \times 47 \mathrm{~mL}$ of deionized water and gave $1.091 \mathrm{~g}(86 \%$ yield) of the desired compound $4 \mathrm{~b}$ as white crystals with $\mathrm{de}=50 \%$ (hexane $/ i-\mathrm{PrOH} 96: 4 v / v$ as eluent, flow rate $=0.6 \mathrm{~mL} / \mathrm{min}$.), retention times $t_{R}(1)=65.92$ and $t_{R}(2)=71.38 \mathrm{~min} .\left[\alpha_{\mathrm{D}}\right]=0.0(c 1.0, \mathrm{MeOH}) . \mathrm{Mp}=116-118{ }^{\circ} \mathrm{C} .{ }^{1} \mathrm{H} \mathrm{NMR}\left(\mathrm{DMSO}-d_{6}\right) \delta=3.73(\mathrm{~s}, 3 \mathrm{H}$, $\left.\mathrm{OCH}_{3}\right), 4.10-4.27\left(\mathrm{~m}, 2 \mathrm{H}, \mathrm{CH}_{2}, \mathrm{H}-2\right), 4.87(\mathrm{dt}, 1 \mathrm{H}, J=7.5,5.1 \mathrm{~Hz}, \mathrm{CH}, \mathrm{H}-1), 5.54$ (br d, $1 \mathrm{H}, J=4.6 \mathrm{~Hz}$, $\mathrm{OH}), 6.17\left(\mathrm{dd}, 1 \mathrm{H}, J=1.8 \mathrm{~Hz}, \mathrm{H}-4^{\prime}\right), 6.88$ (d, 2H, $\left.J=8.7 \mathrm{~Hz}, \mathrm{H}-3^{\prime \prime}, \mathrm{H}-5^{\prime \prime}, \mathrm{Ar}\right), 7.15-7.29$ (m, 2H, H-2", H-6", Ar), $7.42\left(\mathrm{dd}, 1 \mathrm{H}, J=1.8,0.7 \mathrm{~Hz}, \mathrm{H}-3^{\prime}\right), 7.57\left(\mathrm{dd}, 1 \mathrm{H}, J=2.2,0.8 \mathrm{~Hz}, \mathrm{H}-5^{\prime}\right) .{ }^{13} \mathrm{C}$ NMR (DMSO- $d_{6}$ ) $\delta=55.0\left(\mathrm{OCH}_{3}\right), 58.7(\mathrm{C}-2), 71.4(\mathrm{C}-1), 104.6\left(\mathrm{C}-4^{\prime}\right), 113.5\left(\mathrm{C}-3^{\prime \prime}, \mathrm{C}-5^{\prime \prime}\right), 127.2\left(\mathrm{C}-2^{\prime \prime}, \mathrm{C}-6^{\prime \prime}\right), 130.5\left(\mathrm{C}-1^{\prime \prime}\right)$, $134.8\left(\mathrm{C}-5^{\prime}\right), 138.4\left(\mathrm{C}-3^{\prime}\right), 158.5\left(\mathrm{C}-4^{\prime \prime}\right)$. ES ${ }^{+} \mathrm{HRMS}, \mathrm{m} / z=241.0954$ found (calculated for $\mathrm{C}_{12} \mathrm{H}_{14} \mathrm{~N}_{2} \mathrm{O}_{2} \mathrm{Na}$ $[\mathrm{M}+\mathrm{Na}]^{+}$requires 241.0953$)$.

1-(4-Methoxyphenyl)-2-(3-trifluoromethyl-1H-pyrazol-1-yl)ethan-1-ol (4c). According to the standard procedure, the compound $4 \mathrm{c}$ was prepared from 1-(4-methoxyphenyl)-2-(3-trifluoromethyl-1H-pyrazol-1-yl)ethan-1-one $3 \mathrm{c}(1.42 \mathrm{~g}, 5 \mathrm{mmol})$ in $39 \mathrm{~mL}$ of anhydrous methanol after a reaction time of $7 \mathrm{~h}$ using hexane/AcOEt 1:1 $v / v$ as eluent for thin layer chromatography. Washing work-up was realized with $3 \times 47 \mathrm{~mL}$ of deionized water and gave $1.431 \mathrm{~g}\left(94 \%\right.$ yield) of the desired compound $4 \mathrm{c}$ as white powder. $\mathrm{Mp}=110-112{ }^{\circ} \mathrm{C} .{ }^{1} \mathrm{H}$ NMR (DMSO- $\left.d_{6}\right) \delta=3.74\left(\mathrm{~s}, 3 \mathrm{H}, \mathrm{OCH}_{3}\right), 4.27\left(\mathrm{~d}, 2 \mathrm{H}, J=6.5 \mathrm{~Hz}, \mathrm{CH}_{2}, \mathrm{H}-2\right), 4.90(\mathrm{t}, 1 \mathrm{H}, J=6.5 \mathrm{~Hz}, \mathrm{CH}$, $\mathrm{H}-1), 5.63$ (br s, 1H, OH), 6.66 (d, 1H, $\left.J=2.3 \mathrm{~Hz}, \mathrm{H}-4^{\prime}, \mathrm{Ar}\right), 6.90$ (d, 2H, $\left.J=8.6 \mathrm{~Hz}, \mathrm{H}-3^{\prime \prime}, \mathrm{H}-5^{\prime \prime}, \mathrm{Ar}\right)$, $7.28\left(\mathrm{~d}, 2 \mathrm{H}, J=8.3 \mathrm{~Hz}, \mathrm{H}-2^{\prime \prime}, \mathrm{H}-6^{\prime \prime}, \mathrm{Ar}\right), 7.85\left(\mathrm{~s}, 1 \mathrm{H}, \mathrm{H}-5^{\prime}, \mathrm{Ar}\right) .{ }^{13} \mathrm{C}$ NMR $\left(\mathrm{DMSO}-d_{6}\right) \delta=55.0\left(\mathrm{OCH}_{3}\right)$, 55.1 (OCH3), 59.3 (C-2), 71.0 (C-1), 103.7, (C-4'), 103.7 (C-4'), 113.6 (C-2", C-6"), 113.6 (C-2", C-6"), 127.2 (C-3", C-5"), 127.3 (C-3", C-5"), $133.1\left(\mathrm{C}-5^{\prime}\right), 133.2\left(\mathrm{C}-5^{\prime}\right), 134.2\left(\mathrm{C}-1^{\prime \prime}\right), 140.13$ (q, J = 37.1 Hz, CF $)_{3}$, 158.7 (C-4"). ES ${ }^{+}$HRMS, $m / z=309.0824$ found (calculated for $\mathrm{C}_{13} \mathrm{H}_{12} \mathrm{~N}_{2} \mathrm{O}_{2} \mathrm{~F}_{3} \mathrm{Na}[\mathrm{M}+\mathrm{Na}]^{+}$requires 309.0827); 269.0902 found (calculated for $\mathrm{C}_{13} \mathrm{H}_{11} \mathrm{~N}_{2} \mathrm{OF}_{3}\left[\mathrm{M}-\mathrm{H}_{2} \mathrm{O}+\mathrm{H}\right]^{+}$requires 309.0827).

2-(3,5-Bis-trifluoromethyl-1H-pyrazol-1-yl)-1-(4-methoxyphenyl)ethan-1-ol (4d). To a solution of 2-(3,5-bis-trifluoromethyl-1H-pyrazol-1-yl)-1-(4-methoxyphenyl)ethan-1-one $3 \mathbf{d}$ (1.76 g, $5 \mathrm{mmol}$ ) in $31 \mathrm{~mL}$ of anhydrous methanol, sodium borohydride $\mathrm{NaBH}_{4}(0.378 \mathrm{~g}, 10 \mathrm{mmol}, 2$ equiv.) was added in small portions at $0{ }^{\circ} \mathrm{C}$ (ice bath) under magnetic stirring (300 rpm). The resulting mixture was stirred $(500 \mathrm{rpm})$ for $7 \mathrm{~h}$ at room temperature and the reaction solution was monitored by thin layer chromatography on $0.2 \mathrm{~mm}$ plates of silica gel $60 \mathrm{~F}-254$ (Merck) using hexane/AcOEt 1:1 $v / v$ as eluent. After concentration of the reaction mixture in vacuo, $44 \mathrm{~mL}$ of deionized water was added in the crude oily residue, and extraction was conducted with AcOEt $(3 \times 44 \mathrm{~mL})$ in a separating funnel. The combined extracts were washed with $44 \mathrm{~mL}$ of brine and dried over magnesium sulfate. After filtration on a filter paper, the filtrate was concentrated in a rotary evaporator under reduced pressure 
and gave an oily residue which was dried under high vacuum $\left(10^{-2}\right.$ Torr $)$ at $25^{\circ} \mathrm{C}$ for $2 \mathrm{~h}$. The desired compound $4 \mathbf{d}(1.771 \mathrm{~g})$ was obtained as yellowish mobile oil in 98\% yield. ${ }^{1} \mathrm{H}$ NMR (DMSO- $\left.d_{6}\right)$ $\delta=3.74\left(\mathrm{~s}, 3 \mathrm{H}, \mathrm{OCH}_{3}\right), 4.29(\mathrm{dd}, 1 \mathrm{H}, J=13.9,8.9 \mathrm{~Hz}, \mathrm{CH}, \mathrm{H}-2), 4.40(\mathrm{dd}, 1 \mathrm{H}, J=13.9,4.4 \mathrm{~Hz}, \mathrm{CH}, \mathrm{H}-2)$, $5.01(\mathrm{dt}, 1 \mathrm{H}, J=8.9,4.4 \mathrm{~Hz}, \mathrm{CH}, \mathrm{H}-1), 5.73(\mathrm{dd}, 1 \mathrm{H}, J=4.6,0.7 \mathrm{~Hz}, \mathrm{OH}), 6.92$ (d, 2H, J = 8.7 Hz, H-3", H-5", Ar), 7.28 (d, 2H, J = 8.4 Hz, H-2", H-6", Ar), 7.50-7.54 (m, 1H, H-4', Ar). ${ }^{13}$ C NMR (DMSO- $\left.d_{6}\right)$ $\delta=55.1$ (OCH3), 58.8 (C-2), 70.6 (C-1), 106.8 (C-4'), 113.7 (C-3", C-5"), 127.2 (C-2" , C-6"), 133.5 (C-1"), 158.9 (C-4"). ES ${ }^{+}$HRMS, $m / z=377.0700$ found (calculated for $\mathrm{C}_{14} \mathrm{H}_{12} \mathrm{~N}_{2} \mathrm{O}_{2} \mathrm{~F}_{6} \mathrm{Na}[\mathrm{M}+\mathrm{Na}]^{+}$requires 377.0701); 337.0763 found (calculated for $\mathrm{C}_{14} \mathrm{H}_{11} \mathrm{~N}_{2} \mathrm{OF}_{6}\left[\mathrm{M}-\mathrm{H}_{2} \mathrm{O}+\mathrm{H}\right]^{+}$requires 337.0776).

3.1.2. General Procedure for the Synthesis of $(1 R, 1 S) 1-[\beta$-(Phenylalkoxy)-phenethyl]-1H-pyrazolium Hydrochloride (7a-e)

Pellets of potassium hydroxide $\mathrm{KOH}(0.112 \mathrm{~g}, 2 \mathrm{mmol}, 2$ equiv. $)$ were added to a solution of 1-phenyl-2-(1H-pyrazol-1-yl)ethan-1-ol 4 (1 mmol, 1 equiv.) in $3.76 \mathrm{~mL}$ of dry dimethylsulfoxide pa at room temperature. The resulting mixture was stirred vigorously (550 rpm) for 30 min until complete dissolution of $\mathrm{KOH}$, then commercial arylalkyl halide 5 ( $1 \mathrm{mmol}, 1$ equiv.) was added in one portion in the reaction mixture. The reaction mixture was heated at $50{ }^{\circ} \mathrm{C}$ under magnetic stirring (300 rpm) for $48 \mathrm{~h}$. After cooling down to room temperature, $18.7 \mathrm{~mL}$ of saturated brine was added to the reaction mixture and the resulting solution was transferred into a separating funnel. Extraction was conducted with $18.7 \mathrm{~mL}$ of diethyl ether $\mathrm{Et}_{2} \mathrm{O}$, then the organic phase was dried over magnesium sulphate and filtered on a filter paper. The filtrate was concentrated in a rotary evaporator under reduced pressure. The oily crude residue containing1-[ $\beta$-(phenylalkoxy)-phenethyl]-1H-pyrazole 6 was dissolved in appropriate volume of diethyl ether $\mathrm{Et}_{2} \mathrm{O}$ pa under a stream of argon with magnetic stirring (200 rpm). To this homogeneous solution, a commercial solution of $1 \mathrm{M} \mathrm{HCl} \mathrm{(1} \mathrm{equiv.)} \mathrm{in}$ ether was added dropwise rapidly. During mixing at room temperature, the initial pale yellow oil crystallized progressively on the circumference of the round flask and mixing (from $24 \mathrm{~h}$ to 5 days) was pursued until complete crystallization of the desired 1-[ $\beta$-(phenylalkoxy)-phenethyl]-1H-pyrazolium hydrochloride 7. The resulting precipitate was collected by filtration on a Büchner funnel (porosity $\mathrm{N}^{\circ} 4$ ) and washed with dry diethyl ether pa. The desired compound 7 was dried at room temperature for $4 \mathrm{~h}$ and stored in a dessicator.

$(1 R, 1 S)$ 1-[ $\beta-((4-M e t h o x y b e n z y l) o x y)-p h e n e t h y l]-1 H$-pyrazolium hydrochloride (7a). Using the standard procedure from 1-phenyl-2-(1H-pyrazol-1-yl)ethan-1-ol 4a $(0.188 \mathrm{~g}, 1 \mathrm{mmol})$ and 4-methoxybenzyl chloride 5a (0.157 g, $1 \mathrm{mmol}, 1$ equiv.), the 1-[ $\beta$-((4-methoxybenzyl)oxy)-phenethyl]-1H-pyrazole 6a $(0.199 \mathrm{~g}, 0.65 \mathrm{mmol})$ was dissolved in $4.6 \mathrm{~mL}$ of dry diethyl ether pa under a stream of argon. The addition of $0.65 \mathrm{~mL}$ of $1 \mathrm{M} \mathrm{HCl}(0.65 \mathrm{mmol}, 1$ equiv.) produced a viscous gum on the circumference of the round flask after mixing at room temperature for 5 days. Then, this reaction mixture was stored in a refrigerator at $4{ }^{\circ} \mathrm{C}$ for 2 weeks and produced a compact gum. This gum was then manually and carefully triturated in $4 \mathrm{~mL}$ of dry hexane and progressively produced a powder. The resulting suspension was stirred $(200 \mathrm{rpm})$ at room temperature for 5 days, and produced a completely divided powder. The desired salt 7a was collected by filtration on a Büchner funnel (porosity $\mathrm{N}^{\circ} 4$ ) and washed with $0.5 \mathrm{~mL}$ of dry diethyl ether pa. After drying at $25{ }^{\circ} \mathrm{C}$ for $4 \mathrm{~h}$, the 1-[ $\beta$-((4-methoxybenzyl)oxy)-phenethyl]-1H-pyrazolium hydrochloride $7 \mathrm{a}(35.72 \mathrm{mg}, 10 \%$ yield) was obtained as white powder. $\mathrm{Mp}=62-65{ }^{\circ} \mathrm{C} .{ }^{1} \mathrm{H}$ NMR $\left(\mathrm{DMSO}-d_{6}\right) \delta=3.72\left(\mathrm{~s}, 3 \mathrm{H}, \mathrm{OCH}_{3}\right), 4.09(\mathrm{~d}$, $\left.1 \mathrm{H}, J=11.6 \mathrm{~Hz}, \mathrm{CH}, \mathrm{H}-1^{\prime \prime}\right), 4.19-4.32$ (m, 2H, CH, H-1", $\left.\mathrm{H}-1^{\prime}\right), 4.40\left(\mathrm{dd}, 1 \mathrm{H}, J=13.9,8.5 \mathrm{~Hz}, \mathrm{CH}, \mathrm{H}-1^{\prime}\right)$, $4.78\left(\mathrm{dd}, 1 \mathrm{H}, \mathrm{J}=8.4,4.4 \mathrm{~Hz}, \mathrm{CH}, \mathrm{H}-2^{\prime}\right), 6.22$ (t, 1H, J = 2.0 Hz, H-4, Ar), 6.82 (d, 2H, J = 8.6 Hz, H-3b, H-5b, Ar), 6.99 (d, 2H, J = 8.6 Hz, H-2b, H-6b, Ar), 7.27-7.44 (m, 5H, H-2a, H-3a, H-4a, H-5a, H-6a), $7.46(\mathrm{~d}, 1 \mathrm{H}, J=1.8 \mathrm{~Hz}, \mathrm{H}-3, \mathrm{Ar}), 7.62(\mathrm{~d}, 1 \mathrm{H}, J=2.2 \mathrm{~Hz}, \mathrm{H}-5, \mathrm{Ar}) .{ }^{13} \mathrm{C}$ NMR $\left(\mathrm{DMSO}-d_{6}\right) \delta=55.1\left(\mathrm{OCH}_{3}\right)$, $57.0\left(\mathrm{C}-1^{\prime}\right), 69.7\left(\mathrm{C}-1^{\prime \prime}\right), 79.4\left(\mathrm{C}-2^{\prime}\right), 104.9$ (C-4), 113.6 (C-3a, C-5a), 126.8 (C-2a, C-6a), 128.1 (C-4a), 128.6 (C-2a, C-6a), 128.8 (C-3a, C-5a), 129.9 (C-1b), 130.9 (C-5), 138.6 (C-3), 139.0 (C-1a), 158.6 (C-4b). $\mathrm{ES}^{+}$HRMS, $m / z=331.1418$ found (calculated for $\mathrm{C}_{19} \mathrm{H}_{20} \mathrm{~N}_{2} \mathrm{O}_{2} \mathrm{Na}[\mathrm{M}+\mathrm{Na}]^{+}$requires 331.1417). 
$(1 R, \quad 1 S) \quad 1-[\beta-((3-(4-M e t h o x y p h e n y l)$ propyl)oxy)-phenethyl]-1H-pyrazolium hydrochloride (7b). Using the standard procedure from 1-phenyl-2-(1H-pyrazol-1-yl)ethan-1-ol 4a (0.188 g, $1 \mathrm{mmol})$ and 1-(3-bromopropyl)-4-methoxybenzene $5 \mathrm{c}(0.229 \mathrm{~g}, 1 \mathrm{mmol}, 1$ equiv.), the 1-[ $\beta$-((3-phenylpropyl)oxy)-phenethyl]-1H-pyrazole $6 \mathbf{b}(0.151 \mathrm{~g}, 0.45 \mathrm{mmol})$ was dissolved in $3 \mathrm{~mL}$ of dry diethyl ether pa under a stream of argon. The addition of $0.45 \mathrm{~mL}$ of $1 \mathrm{M} \mathrm{HCl}$ ( $0.45 \mathrm{mmol}, 1$ equiv.) produced a pale yellow viscous oil that crystallized progressively on the circumference of the round flask, and mixing ( $200 \mathrm{rpm}, 72 \mathrm{~h}$ ) was pursued until complete crystallization of the oily gum. The desired salt $\mathbf{7 b}$ was collected by filtration on a Büchner funnel (porosity $\mathrm{N}^{\circ} 4$ ) and washed with $3 \times 0.5 \mathrm{~mL}$ of dry diethyl ether pa. After drying at $25^{\circ} \mathrm{C}$ for $4 \mathrm{~h}$, the 1-[ $\beta$-((3-(4-methoxyphenyl)propyl)oxy)-phenethyl]- $1 H$-pyrazolium hydrochloride $7 \mathbf{b}$ (78.3 mg, $21 \%$ yield) was obtained as white powder. $\mathrm{Mp}=76-80{ }^{\circ} \mathrm{C} .{ }^{1} \mathrm{H}$ NMR $\left(\mathrm{DMSO}-d_{6}\right) \delta=1.62(\mathrm{dt}, 2 \mathrm{H}, J=8.2$, $\left.6.2 \mathrm{~Hz}, \mathrm{CH}_{2}, \mathrm{H}-2^{\prime \prime}\right), 2.36\left(\mathrm{dd}, 2 \mathrm{H}, J=8.4,6.7 \mathrm{~Hz}, \mathrm{CH}_{2}, \mathrm{H}-3^{\prime \prime}\right), 3.05\left(\mathrm{dt}, 1 \mathrm{H}, J=9.5,6.1 \mathrm{~Hz}, \mathrm{CH}, \mathrm{H}-1^{\prime \prime}\right)$, $3.22\left(\mathrm{dt}, 1 \mathrm{H}, J=9.5,6.0 \mathrm{~Hz}, \mathrm{CH}, \mathrm{H}-1^{\prime \prime}\right), 3.69\left(\mathrm{~s}, \mathrm{OCH}_{3}\right), 4.23\left(\mathrm{dd}, 1 \mathrm{H}, J=13.9,4.4 \mathrm{~Hz}, \mathrm{CH}, \mathrm{H}-1^{\prime}\right), 4.37(\mathrm{dd}$, $\left.1 \mathrm{H}, J=13.9,8.7 \mathrm{~Hz}, \mathrm{CH}, \mathrm{H}-1^{\prime}\right), 4.69\left(\mathrm{dd}, 1 \mathrm{H}, J=8.7,4.2 \mathrm{~Hz}, \mathrm{CH}, \mathrm{H}-2^{\prime}\right), 6.23(\mathrm{t}, 1 \mathrm{H}, J=2.1 \mathrm{~Hz}, \mathrm{H}-4$, Ar), $6.77(\mathrm{~d}, 2 \mathrm{H}, J=8.6 \mathrm{~Hz}, \mathrm{H}-3 \mathrm{~b}, \mathrm{H}-5 \mathrm{~b}, \mathrm{Ar}), 6.94(\mathrm{~d}, 2 \mathrm{H}, J=8.6 \mathrm{~Hz}, \mathrm{H}-2 \mathrm{~b}, \mathrm{H}-6 \mathrm{~b}, \mathrm{Ar}), 7.27-7.44$ (m, 5H, H-2a, H-3a, H-4a, H-5a, H-6a, Ar), 7.46-7.50 (m, 1H, H-3), 7.68 (dd, 1H, J = 2.3, 0.7 Hz, H-5). ${ }^{13} \mathrm{C}$ NMR $\left(\mathrm{DMSO}-d_{6}\right) \delta=30.4\left(\mathrm{C}-3^{\prime \prime}\right), 31.1\left(\mathrm{C}-2^{\prime \prime}\right), 54.9(\mathrm{OCH} 3), 57.2\left(\mathrm{C}-1^{\prime}\right), 67.4\left(\mathrm{C}-1^{\prime \prime}\right), 80.1\left(\mathrm{C}-2^{\prime}\right), 104.9(\mathrm{C}-4)$, 113.6 (C-3b, C-5b), 126.7 (C-2a, C-6a), 128.0 (C-4a), 128.5 (C-3a, C-5a), 129.2 (C-2b, C-6b), 131.0 (C-5), 133.4 (C-1b), 138.4 (C-3), 139.3 (C-1a), 157.3 (C-4b). ES ${ }^{+}$HRMS, $m / z=359.1733$ found (calculated for $\mathrm{C}_{21} \mathrm{H}_{24} \mathrm{~N}_{2} \mathrm{O}_{2} \mathrm{Na}[\mathrm{M}+\mathrm{Na}]^{+}$requires 359.1735 ); 337.1906 found (calculated for $\mathrm{C}_{21} \mathrm{H}_{25} \mathrm{~N}_{2} \mathrm{O}_{2}[\mathrm{M}+\mathrm{H}]^{+}$ requires 337.1916).

$(1 R$, 1S) 1-[3-((4-Methoxybenzyl)oxy)-(4-methoxyphenethyl]-1H-pyrazolium hydrochloride (7c). Using the standard procedure from 1-(4-methoxyphenyl)-2-(1H-pyrazol-1-yl)ethan-1-ol 4b (0.218 g, $1 \mathrm{mmol})$ and 4-methoxybenzyl chloride 5a $(0.157 \mathrm{~g}, 1 \mathrm{mmol}, 1$ equiv.), the 1-[ $\beta$-((4-methoxybenzyl)oxy)-(4-methoxyphenethyl]-1H-pyrazole 6c $(0.231 \mathrm{~g}, 0.68 \mathrm{mmol})$ was dissolved in $4.57 \mathrm{~mL}$ of dry diethyl ether pa under a stream of argon. The addition of $0.68 \mathrm{~mL}$ of $1 \mathrm{M} \mathrm{HCl}$ (0.68 mmol, 1 equiv.) produced a pale pink viscous oil that crystallized rapidly (30 min.) on the circumference of the round flask, and mixing $(200 \mathrm{rpm}, 72 \mathrm{~h})$ was pursued until complete crystallization of the viscous gum into divided powder. The desired salt $7 \mathrm{c}$ was collected by filtration on a Büchner funnel (porosity $\mathrm{N}^{\circ} 4$ ) and washed with $3 \times 0.5 \mathrm{~mL}$ of dry diethyl ether pa. After drying at $25{ }^{\circ} \mathrm{C}$ for $4 \mathrm{~h}$, the 1 -[ $\beta$-((4-methoxybenzyl)oxy)-(4-methoxyphenethyl]- $1 \mathrm{H}$-pyrazolium hydrochloride $7 \mathrm{c}\left(123.7 \mathrm{mg}, 33 \%\right.$ yield) was obtained as white powder. $\mathrm{Mp}=112-113^{\circ} \mathrm{C} .{ }^{1} \mathrm{H} \mathrm{NMR}$ $\left(\mathrm{DMSO}_{6}\right) \delta=3.72\left(\mathrm{~s}, 3 \mathrm{H}, \mathrm{OCH}_{3}\right), 3.76\left(\mathrm{~s}, 3 \mathrm{H}, \mathrm{OCH}_{3}\right), 4.06\left(\mathrm{~d}, 1 \mathrm{H}, J=11.6 \mathrm{~Hz}, \mathrm{CH}, \mathrm{H}-1^{\prime \prime}\right), 4.16-4.30$ (m, 2H, CH, H-1', $\left.\mathrm{H}-1^{\prime \prime}\right), 4.40\left(\mathrm{dd}, 1 \mathrm{H}, J=13.8,8.5 \mathrm{~Hz}, \mathrm{CH}, \mathrm{H}-1^{\prime}\right), 4.71(\mathrm{dd}, 1 \mathrm{H}, J=8.4,4.5 \mathrm{~Hz}, \mathrm{CH}$, H-2' $), 6.22(\mathrm{t}, 1 \mathrm{H}, J=2.0 \mathrm{~Hz}, \mathrm{H}-4, \mathrm{Ar}), 6.82(\mathrm{~d}, 2 \mathrm{H}, J=8.6 \mathrm{~Hz}, \mathrm{H}-3 \mathrm{a}, \mathrm{H}-5 \mathrm{a}, \mathrm{Ar}), 6.89-7.03(\mathrm{~m}, 4 \mathrm{H}, \mathrm{H}-2 \mathrm{a}$ H-6a, H-3b, H-5b, Ar), 7.26 (d, 2H, J = 8.6 Hz, H-2b, H-6b, Ar), 7.47 (d, 1H, J = 1.9 Hz, H-3, Ar), 7.62 (d, $1 \mathrm{H}, J=2.2 \mathrm{~Hz}, \mathrm{H}-5, \mathrm{Ar}) .{ }^{13} \mathrm{C}$ NMR $\left(\mathrm{DMSO}-d_{6}\right) \delta=55.1\left(\mathrm{OCH}_{3}\right), 55.1\left(\mathrm{OCH}_{3}\right), 57.0\left(\mathrm{C}-1^{\prime}\right), 69.3\left(\mathrm{C}-1^{\prime \prime}\right)$, 78.9 (C-2'), 104.9 (C-4), 113.6 (C-3a, C-5a), 114.0 (C-3b, C-5b), 128.2 (C-2a C-6a), 128.8 (C-2b, C-6b), 130.0 5 (C-1a), 130.8 (C-1b), 130.9 (C-5), 138.5 (C-3), 158.6 (C-4a), 159.1 (C-4b). ES ${ }^{+}$HRMS, $m / z=361.1526$ found (calculated for $\mathrm{C}_{20} \mathrm{H}_{22} \mathrm{~N}_{2} \mathrm{O}_{3} \mathrm{Na}[\mathrm{M}+\mathrm{Na}]^{+}$requires 361.1528); 339.1715 found (calculated for $\mathrm{C}_{20} \mathrm{H}_{23} \mathrm{~N}_{2} \mathrm{O}_{3}[\mathrm{M}+\mathrm{H}]^{+}$requires 339.1709).

$(1 R, 1 S)$ 1-[ $\beta$-((4-Methoxyphenyl)-(3-(4-methoxyphenyl)propoxyethyl)]-1H-pyrazolium hydrochloride (7d). Using the standard procedure from 1-(4-methoxyphenyl)-2-(1H-pyrazol-1-yl)ethan-1-ol $\mathbf{4 b}$ $(0.218 \mathrm{~g}, 1 \mathrm{mmol})$ and 1-(3-bromopropyl)-4-methoxybenzene $5 \mathrm{c}(0.229 \mathrm{~g}, 1 \mathrm{mmol}, 1$ equiv.), the 1-[ $\beta$-((4-methoxyphenyl)-(3-(4-methoxyphenyl)propoxyethyl)]-1H-pyrazole $6 \mathrm{~d}$ ( $0.156 \mathrm{~g}, 0.42 \mathrm{mmol})$ was dissolved in $2.84 \mathrm{~mL}$ of dry diethyl ether pa under a stream of argon. The addition of $0.42 \mathrm{~mL}$ of $1 \mathrm{M} \mathrm{HCl}(0.42 \mathrm{mmol}, 1$ equiv.) produced a pale pink viscous oil that crystallized $(12 \mathrm{~h})$ on the circumference of the round flask, and mixing $(200 \mathrm{rpm}, 72 \mathrm{~h})$ was pursued until complete crystallization of the viscous gum. The desired salt $7 \mathbf{d}$ was collected by filtration on a Büchner 
funnel (porosity $\mathrm{N}^{\circ} 4$ ) and washed with $3 \times 0.5 \mathrm{~mL}$ of dry diethyl ether pa. After drying at $25^{\circ} \mathrm{C}$ for $4 \mathrm{~h}$, the 1-[ $\beta$-((4-methoxyphenyl)-(3-(4-methoxyphenyl)propoxyethyl)]-1H-pyrazolium hydrochloride 7d $\left(72.53 \mathrm{mg}, 18 \%\right.$ yield) was obtained as white powder. $\mathrm{Mp}=92-94{ }^{\circ} \mathrm{C} .{ }^{1} \mathrm{H}$ NMR $\left(\mathrm{DMSO}-d_{6}\right) \delta=1.47-1.70$ $\left(\mathrm{m}, 2 \mathrm{H}, \mathrm{CH}_{2}, \mathrm{H}-2^{\prime \prime}\right), 2.36$ (t, 2H, J = $\left.7.5 \mathrm{~Hz}, \mathrm{CH}_{2}, \mathrm{H}-3^{\prime \prime}\right), 3.03$ (dt, 1H, J = 9.6, $\left.6.2 \mathrm{~Hz}, \mathrm{CH}, \mathrm{H}-1^{\prime \prime}\right), 3.19$ (dt, $\left.1 \mathrm{H}, J=9.5,6.0 \mathrm{~Hz}, \mathrm{CH}, \mathrm{H}-1^{\prime \prime}\right), 3.69\left(\mathrm{~s}, 3 \mathrm{H}, \mathrm{OCH}_{3}\right), 3.75\left(\mathrm{~s}, 3 \mathrm{H}, \mathrm{OCH}_{3}\right), 4.18(\mathrm{dd}, 1 \mathrm{H}, J=13.8,4.3 \mathrm{~Hz}$, $\left.\mathrm{CH}, \mathrm{H}-1^{\prime}\right), 4.35\left(\mathrm{dd}, 1 \mathrm{H}, J=13.8,8.7 \mathrm{~Hz}, \mathrm{CH}, \mathrm{H}-1^{\prime}\right), 4.62\left(\mathrm{dd}, 1 \mathrm{H}, J=8.7,4.2 \mathrm{~Hz}, \mathrm{CH}, \mathrm{H}-2^{\prime}\right), 6.22(\mathrm{t}, 1 \mathrm{H}$, $J=2.0 \mathrm{~Hz}, \mathrm{H}-4, \mathrm{Ar}), 6.77$ (d, 2H, $J=8.6 \mathrm{~Hz}, \mathrm{H}-3 \mathrm{~b}, \mathrm{H}-5 \mathrm{~b}, \mathrm{Ar}), 6.86-7.02$ (m, 4H, H-3a, H-5a, H-2b, H-6b, Ar), $7.26(\mathrm{~d}, 2 \mathrm{H}, J=8.6 \mathrm{~Hz}, \mathrm{H}-2 \mathrm{a}, \mathrm{H}-6 \mathrm{a}, \mathrm{Ar}), 7.47$ (d, 1H, J = 1.8 Hz, H-3, Ar), 7.67 (d, 1H, J = 2.2 Hz, H-5, Ar). ${ }^{13} \mathrm{C}$ NMR (DMSO- $\left.d_{6}\right) \delta=30.4\left(\mathrm{C}-3^{\prime \prime}\right), 31.1\left(\mathrm{C}-2^{\prime \prime}\right), 54.9\left(\mathrm{OCH}_{3}\right), 55.1\left(\mathrm{OCH}_{3}\right), 57.2\left(\mathrm{C}-1^{\prime}\right), 67.0\left(\mathrm{C}-1^{\prime \prime}\right)$, 79.7 (C-2') 104.9 (C-4), 113.6 (C-3b, C-5b), 113.9 (C-3a, C-5a), 128.0 (C-2a, C-6a), 129.2 (C-2b, C-6b), 130.8 (C-3), 131.1 (C-1a), 133.4 (C-1b), 138.5 (C-5), 157.3 (C-4b), 159.0 (C-4a). ES ${ }^{+}$HRMS, $m / z=389.1838$ found (calculated for $\mathrm{C}_{22} \mathrm{H}_{26} \mathrm{~N}_{2} \mathrm{O}_{3} \mathrm{Na}[\mathrm{M}+\mathrm{Na}]^{+}$requires 389.1841).

$(1 R, \quad 1 S) \quad 1-[\beta-((4-M e t h o x y p h e n y l)-(3-p h e n y l p r o p o x y e t h y l)]-1 H$-pyrazolium hydrochloride (7e). Using the standard procedure from 1-(4-methoxyphenyl)-2-(1H-pyrazol-1-yl)ethan-1-ol 4b (0.218 g, $1 \mathrm{mmol})$ and 1-bromo-3-phenylpropane 5d (0.199 g, $1 \mathrm{mmol}, 1$ equiv.), the 1 -[ $\beta$-((4-methoxyphenyl)-(3-phenylpropoxyethyl)]-1H-pyrazole $\quad 6 e \quad\left(\begin{array}{lllll}0.124 & \mathrm{~g}, & 0.37 \mathrm{mmol})\end{array}\right.$ was dissolved in $2.5 \mathrm{~mL}$ of dry diethyl ether pa under a stream of argon. The addition of $0.37 \mathrm{~mL}$ of $1 \mathrm{M} \mathrm{HCl}$ (0.37 mmol, 1 equiv.) produced a translucent colourless viscous oil that crystallized progressively $(24 \mathrm{~h}$ ) on the circumference of the round flask, and mixing (200 rpm, $72 \mathrm{~h}$ ) was pursued until complete crystallization in divided powder. The desired salt $7 \mathrm{e}$ was collected by filtration on a Büchner funnel (porosity $\mathrm{N}^{\circ} 4$ ) and washed with $3 \times 0.5 \mathrm{~mL}$ of dry diethyl ether pa. After drying at $25{ }^{\circ} \mathrm{C}$ for $4 \mathrm{~h}$, the 1-[ $\beta$-((4-methoxyphenyl)-(3-phenylpropoxyethyl)]-1H-pyrazolium hydrochloride 7d $\left(82.04 \mathrm{mg}, 22 \%\right.$ yield) was obtained as white powder. Mp $=87-89{ }^{\circ} \mathrm{C} .{ }^{1} \mathrm{H}$ NMR $\left(\mathrm{DMSO}-d_{6}\right) \delta=$ 1.54-1.76 (m, 2H, CH, $\left.\mathrm{H}-\mathrm{C}^{\prime \prime}\right)$, 2.37-2.46 (m, 2H, $\left.\mathrm{CH}_{2}, \mathrm{H}-3^{\prime \prime}\right), 3.04$ (dt, 1H, J = 9.6, 6.1 Hz, CH, H-1"), $3.21\left(\mathrm{dt}, 1 \mathrm{H}, \mathrm{J}=9.6,6.0 \mathrm{~Hz}, \mathrm{CH}, \mathrm{H}-1^{\prime \prime}\right), 3.75\left(\mathrm{~s}, 3 \mathrm{H}, \mathrm{OCH}_{3}\right), 4.18\left(\mathrm{dd}, 1 \mathrm{H}, J=13.8,4.3 \mathrm{~Hz}, \mathrm{CH}, \mathrm{H}-1^{\prime}\right)$, $4.35\left(\mathrm{dd}, 1 \mathrm{H}, J=13.8,8.7 \mathrm{~Hz}, \mathrm{CH}, \mathrm{H}_{-1}^{\prime}\right), 4.63\left(\mathrm{dd}, 1 \mathrm{H}, J=8.7,4.3 \mathrm{~Hz}, \mathrm{CH}, \mathrm{H}-2^{\prime}\right), 6.21(\mathrm{t}, 1 \mathrm{H}, J=2.1 \mathrm{~Hz}$, H-4, Ar), 6.92 (d, 2H, J = 8.7 Hz, H-3a, H-5a, Ar), 6.99-7.06 (m, 2H, H-2b, H-6b, Ar), 7.08-7.17 (m, 1H, H-4b, Ar), 7.17-7.31 (m, 4H, H-2a H-6a, H-3b, H-5b, Ar), 7.46 (dd, 1H, J = 1.9, 0.7 Hz, H-3, Ar), 7.66 (dd, $1 \mathrm{H}, J=2.3,0.7 \mathrm{~Hz}, \mathrm{H}-5$, Ar). ${ }^{13} \mathrm{C}$ NMR $\left(\mathrm{DMSO}-d_{6}\right) \delta=30.9\left(\mathrm{C}-2^{\prime \prime}\right), 31.4\left(\mathrm{C}-3^{\prime \prime}\right), 55.1\left(\mathrm{OCH}_{3}\right), 57.2\left(\mathrm{C}-1^{\prime}\right)$, 67.1 (C-1") 79.7 (C-2'), 104.9 (C-4), 113.9 (C-3a, C-5a), 125.7 (C-4b), 128.1 (C-2a, C-6a), 128.2 (C-3b, C-5b), 128.4 (C-2b, C-6b), 130.8 (C-5), 131.2 (C-1a), 138.6 (C-3), 141.7 (C-1b), 159.1 (C-4a). ES ${ }^{+}$HRMS, $^{-}$ $m / z=359.1736$ found (calculated for $\mathrm{C}_{21} \mathrm{H}_{24} \mathrm{~N}_{2} \mathrm{O}_{2} \mathrm{Na}[\mathrm{M}+\mathrm{Na}]^{+}$requires 359.1736).

3.1.3. Resolution of $( \pm)-(1 R, 1 S)$ 1-(4-Methoxyphenyl)-2-(1H-pyrazol-1-yl)ethan-1-ol (4b) with (-)-(1R)-10-Camphorsulfonic Acid and (+)-(1S)-10-Camphorsulfonic Acid by Two Convergent Methods of Half-Quantities

Method 1 from (-)-(1R)-CSA:

(-)-(1S) 1-(4-methoxyphenyl)-2-(1H-pyrazol-1-yl)ethan-1-ol (4b): To a stirred solution of $( \pm)$ 1-(4-methoxyphenyl)-2-(1H-pyrazol-1-yl)ethan-1-ol 4b $(0.5 \mathrm{~g}, 2.29 \mathrm{mmol})$ in $5 \mathrm{~mL}$ of dry acetone, a solution of $(-)-(1 R)-10$-camphorsulfonic acid $(0.266 \mathrm{~g}, 1.145 \mathrm{mmol})$ in $2 \mathrm{~mL}$ of dry acetone was added dropwise at room temperature for $5 \mathrm{~min}$. Stirring ( $300 \mathrm{rpm})$ was pursued for $12 \mathrm{~h}$ at $25^{\circ} \mathrm{C}$. It is interesting to note that during the addition of the solution of $(-)-(1 R)-\mathrm{CSA}$, the formation of a white fine suspension of diastereomer appeared in the reaction mixture. This first fraction of diastereomer salt was collected by filtration on a Büchner funnel (porosity $\mathrm{N}^{\circ} 4$ ), washed thoroughly with $4 \times 0.3 \mathrm{~mL}$ of dry acetone, and dried in vacuum to give $0.363 \mathrm{~g}$ of the desired the salt $(-)-(1 S)-4 \mathrm{~b} /(-)-(1 R)-C S A(>85 \%$ de). This salt was recrystallized in dry acetone and afforded $0.271 \mathrm{~g}$ $(52 \%$ isolated yield) of salt $(-)-(1 S)-4 b /(-)-(1 R)-C S A(>97 \%$ de). This salt was dissolved in $0.6 \mathrm{~mL}$ of dry acetone under magnetic stirring (300 rpm), and to this suspension, 0.02 equiv. of racemic (土) 1-(4-methoxyphenyl)-2-(1H-pyrazol-1-yl)ethan-1-ol 4b was added for diastereomeric enrichment. 
This suspension was stirred for $18 \mathrm{~h}$ at room temperature. The enriched salt was successively filtered on a Büchner funnel, washed with $0.5 \mathrm{~mL}$ of dry acetone, dried in vacuum, and recrystallized in dry acetone that produced $0.251 \mathrm{~g}(48 \%$ yield) of $(-)-(1 S)-4 \mathrm{~b} /(-)-(1 R)-C S A(>99 \%$ de) as white powder; $\left[\alpha_{\mathrm{D}}\right]=-6,0(c 1.0, \mathrm{MeOH})$.

Starting from $200 \mathrm{mg}$ of the pure salt $(-)-(1 S)-4 b /(-)-(1 R)-C S A$, a mixed suspension was prepared in $2.5 \mathrm{~mL}$ of dry methanol and 1 equiv. of commercial MeONa was added in one portion. The resulting reaction mixture was stirred at room temperature for $12 \mathrm{~h}$ and then concentrated in a rotary evaporator under reduced pressure. The crude solid residue was washed thoroughly with $4 \times 2 \mathrm{~mL}$ of deionized water. The insoluble compound was collected by filtration on a Büchner funnel (porosity $\mathrm{N}^{\circ} 4$ ) and dried in vacuum, which produced $0.096 \mathrm{~g}$ (38\% yield) of the desired (-)-(1S) 1-(4-methoxyphenyl)-2-(1H-pyrazol-1-yl)ethan-1-ol 4b (99\% ee); $\left[\alpha_{\mathrm{D}}\right]=-10,0$ (c 1.0, $\left.\mathrm{MeOH}\right)$ and $\mathrm{Mp}=113-114^{\circ} \mathrm{C}$.

Recovery of the (+)-(1R) 1-(4-methoxyphenyl)-2-(1H-pyrazol-1-yl)ethan-1-ol $4 \mathbf{b}$ : The filtrate of the first fraction was submitted to concentration in a rotary evaporator under reduced pressure and afforded $0.345 \mathrm{~g}$ of a crude residue. To this solid residue, $14.5 \mathrm{~mL}$ of dry toluene was added and the resulting suspension was submitted to magnetic stirring for $4 \mathrm{~h}$. This suspension was filtered through a Büchner funnel (porosity $\mathrm{N}^{\circ} 4$ ) and the filtrate was concentrated in a rotary evaporator under reduced pressure and produced $0.190 \mathrm{~g}(0.87 \mathrm{mmol})$ of a white powder of $(+)-(1 R)-4 \mathbf{b}(65 \%$ ee). This white solid was dissolved in $3.8 \mathrm{~mL}$ of dry acetone under magnetic stirring and to the resulting solution, a solution of (+)-(1S)-CSA (0.2 g, $0.87 \mathrm{mmol}, 1$ equiv.) in $1.52 \mathrm{~mL}$ of dry acetone was added dropwise. During the addition of the (+)-(1S)-CSA solution, a fine suspension appeared in the mixture, which was stirred at room temperature for $12 \mathrm{~h}$. The new diastereomer salt was collected by filtration then washed with $4 \times 0.25 \mathrm{~mL}$ of dry acetone, dried in vacuum, which gave $0.249 \mathrm{~g}$ ( $63 \%$ yield) of the $(+)-(1 R)-4 b /(+)-(1 S)-C S A$ salt $(96 \%$ de) as white powder. From this salt, diastereomeric enrichment was conducted with 0.04 equiv. of racemic $( \pm)$ 1-(4-methoxyphenyl)-2-(1H-pyrazol-1-yl)ethan-1-ol 4b. The enriched suspension was stirred for $18 \mathrm{~h}$ at room temperature and the resulting enriched salt was successively submitted to filtration on a Büchner funnel, washing with $0.5 \mathrm{~mL}$ of dry acetone, drying in vacuum, and finally recrystallisation in dry acetone which gave $0.202 \mathrm{mg}$ (51\% yield) of $(+)-(1 R)-4 \mathbf{b} /(+)-(1 S)-C S A\left(>99 \%\right.$ de) as white needles; $\left[\alpha_{\mathrm{D}}\right]=+6,0(c$ 1.0, $\mathrm{MeOH})$.

Starting from $200 \mathrm{mg}$ of the pure salt $(+)-(1 R)-4 \mathbf{b} /(+)-(1 S)-C S A$, a mixed suspension was prepared in $2.5 \mathrm{~mL}$ of dry methanol, and 1 equiv. of commercial MeONa was added in one portion. The resulting reaction mixture was stirred at room temperature for $12 \mathrm{~h}$ and then concentrated in a rotary evaporator under reduced pressure. The crude solid residue was washed thoroughly with $4 \times 2 \mathrm{~mL}$ of deionized water. The insoluble compound was collected by filtration on a Büchner funnel (porosity $\left.\mathrm{N}^{\circ} 4\right)$ and dried in vacuum which gave $0.078 \mathrm{~g}$ (41\% yield) of the desired $(+)-(1 R)$ 1-(4-methoxyphenyl)-2-(1H-pyrazol-1-yl)ethan-1-ol 4b (99\% ee); $\left[\alpha_{\mathrm{D}}\right]=+10,0(c$ 1.0, $\mathrm{MeOH})$ and $\mathrm{Mp}=110-111^{\circ} \mathrm{C}$.

Method 2 with (+)-(1S)-CSA:

(+)-(1R) 1-(4-Methoxyphenyl)-2-(1H-pyrazol-1-yl)ethan-1-ol (4b): To a stirred solution of $( \pm)$ 1-(4-methoxyphenyl)-2-(1H-pyrazol-1-yl)ethan-1-ol $4 \mathrm{~b}(0.5 \mathrm{~g}, 2.29 \mathrm{mmol})$ in $5 \mathrm{~mL}$ of dry acetone, a solution of (+)-(1S)-10-camphorsulfonic acid $(0.266 \mathrm{~g}, 1.145 \mathrm{mmol})$ in $2 \mathrm{~mL}$ of dry acetone was added dropwise at room temperature for $5 \mathrm{~min}$. Stirring (300 rpm) was pursued for $12 \mathrm{~h}$ at $25^{\circ} \mathrm{C}$. It is interesting to note that during the addition of the solution of (+)-(1S)-CSA, the formation of a white fine suspension of diastereomer appeared in the reaction mixture. This first fraction of diastereomer salt was collected by filtration on a Büchner funnel (porosity $\mathrm{N}^{\circ} 4$ ), washed thoroughly with $4 \times 0.3 \mathrm{~mL}$ of dry acetone, and dried in vacuum to give $0.358 \mathrm{~g}$ of the desired the salt $(+)-(1 R)-4 \mathrm{~b} /(+)-(1 S)-C S A(>87 \%$ de). This salt was recrystallized in dry acetonitrile and afforded 
$0.280 \mathrm{~g}(54 \%$ isolated yield) of salt $(+)-(1 R)-4 \mathbf{b} /(+)-(1 S)-C S A(>96 \%$ de). This salt was dissolved in $0.6 \mathrm{~mL}$ of dry acetone under magnetic stirring $(300 \mathrm{rpm})$ and to this suspension was added 0.02 equiv. of racemic $( \pm)$ 1-(4-methoxyphenyl)-2-(1H-pyrazol-1-yl)ethan-1-ol $\mathbf{4 b}$ for diastereomeric enrichment. This suspension was stirred for $18 \mathrm{~h}$ at room temperature. The enriched salt was successively filtered on a Büchner funnel, washed with $0.5 \mathrm{~mL}$ of dry acetone, dried in vacuum, and recrystallized in dry acetone that gave $0.229 \mathrm{~g}(44 \%$ yield) of $(+)-(1 R)-4 \mathbf{b} /(+)-(1 S)-C S A(>99 \%$ de) as white powder; $\left[\alpha_{\mathrm{D}}\right]=+6,0(c 1.0, \mathrm{MeOH})$.

Starting from $200 \mathrm{mg}$ of the pure salt $(+)-(1 R)-4 \mathbf{b} /(+)-(1 S)-C S A$, a mixed suspension was prepared in $2.5 \mathrm{~mL}$ of dry methanol, and 1 equiv. of commercial MeONa was added in one portion. The resulting reaction mixture was stirred at room temperature for $12 \mathrm{~h}$ and then concentrated in a rotary evaporator under reduced pressure. The crude solid residue was washed thoroughly with $4 \times 2 \mathrm{~mL}$ of deionized water. The insoluble compound was collected by filtration on a Büchner funnel (porosity $\left.\mathrm{N}^{\circ} 4\right)$ and dried in vacuum, which gave $0.089 \mathrm{~g}$ (35\% yield) of the desired $(+)-(1 R)$ 1-(4-methoxyphenyl)-2-(1H-pyrazol-1-yl)ethan-1-ol $4 \mathbf{b}$ (99\% ee); $\left[\alpha_{\mathrm{D}}\right]=+10,0(c 1.0, \mathrm{MeOH})$ and $\mathrm{Mp}=$ $110-111^{\circ} \mathrm{C}$.

Recovery of the (-)-(1S) 1-(4-methoxyphenyl)-2-(1H-pyrazol-1-yl)ethan-1-ol $\mathbf{4 b}$ : The filtrate of the first fraction was submitted to concentration in a rotary evaporator under reduced pressure and afforded $0.366 \mathrm{~g}$ of a crude residue. To this solid residue, $14.5 \mathrm{~mL}$ of dry toluene was added and the resulting suspension was submitted to magnetic stirring for $4 \mathrm{~h}$. This suspension was filtered through a Büchner funnel (porosity $\mathrm{N}^{\circ} 4$ ) and the filtrate was concentrated in a rotary evaporator under reduced pressure and produced $0.207 \mathrm{~g}(0.95 \mathrm{mmol})$ of a white powder of $(-)-(1 \mathrm{~S})-4 \mathbf{b}(74 \% \mathrm{ee})$. This white solid was dissolved in $4.2 \mathrm{~mL}$ of dry acetone under magnetic stirring and to the resulting solution, a solution of $(-)-(1 R)-C S A(0.219 \mathrm{~g}, 0.95 \mathrm{mmol}, 1$ equiv.) in $1.66 \mathrm{~mL}$ of dry acetone was added dropwise. During the addition of the $(-)-(1 R)$-CSA solution, a fine suspension appeared in the mixture, which was stirred at room temperature for $12 \mathrm{~h}$. The new diastereomer salt was collected by filtration then washed with $4 \times 0.25 \mathrm{~mL}$ of dry acetone and dried in vacuum, which gave $0.285 \mathrm{~g}$ ( $66 \%$ yield) of the $(-)-(1 S)-4 \mathbf{b} /(-)-(1 R)-C S A$ salt $(98 \%$ de) as white powder. From this salt, diastereomeric enrichment was conducted with 0.01 equiv. of racemic $( \pm)$ 1-(4-methoxyphenyl)-2-(1H-pyrazol-1-yl)ethan-1-ol $4 \mathbf{b}$. The enriched suspension was stirred for $18 \mathrm{~h}$ at room temperature and the resulting enriched salt was successively submitted to filtration on a Büchner funnel, washing with $0.5 \mathrm{~mL}$ of dry acetone, drying in vacuum, and finally recrystallisation in dry acetone which gave $0.258 \mathrm{mg}$ ( $60 \%$ yield) of $(-)-(1 S)-4 \mathbf{b} /(-)-(1 R)-C S A\left(>99 \%\right.$ de) as white needles; $\left[\alpha_{D}\right]=-6,0(c 1.0, \mathrm{MeOH})$.

Starting from $200 \mathrm{mg}$ of the pure salt $(-)-(1 S)-4 \mathbf{b} /(-)-(1 R)-C S A$, a mixed suspension was prepared in $2.5 \mathrm{~mL}$ of dry methanol, and 1 equiv. of commercial MeONa was added in one portion. The resulting reaction mixture was stirred at room temperature for $12 \mathrm{~h}$ and then concentrated in a rotary evaporator under reduced pressure. The crude solid residue was washed thoroughly with $4 \times 2 \mathrm{~mL}$ of deionized water. The insoluble compound was collected by filtration on a Büchner funnel (porosity $\left.\mathrm{N}^{\circ} 4\right)$ and dried in vacuum which gave $0.090 \mathrm{~g}$ (43\% yield) of the desired (-)-(1S) 1-(4-methoxyphenyl)-2-(1H-pyrazol-1-yl)ethan-1-ol $4 \mathbf{b}$ ( $>99 \%$ ee); [ $\left.\alpha_{\mathrm{D}}\right]=-10,0$ (c 1.0, $\left.\mathrm{MeOH}\right)$ and $\mathrm{Mp}$ $=113-114{ }^{\circ} \mathrm{C}$.

$(-)-(1 S)-4 \mathbf{b} /(-)-(1 R)-C S A$ salt: Yield $=48 \%$. White powder, $\mathrm{Mp}=168-170{ }^{\circ} \mathrm{C} .\left[\alpha_{\mathrm{D}}\right]=-6.0$ (c 1.0, $\mathrm{MeOH}$ ) and $>99 \%$ de (retention time $t_{R}=34.01 \mathrm{~min}$. using hexane $/ i-\mathrm{PrOH} 94: 6 v / v$ as eluent, flow rate $=0.8 \mathrm{~mL} / \mathrm{min}$.). ${ }^{1} \mathrm{H}$ NMR $\left(\mathrm{DMSO}-d_{6}\right) \delta=0.75\left(\mathrm{~s}, 3 \mathrm{H}, \mathrm{C}-7{ }^{\prime \prime} \mathrm{CH}_{3}\right), 1.04\left(\mathrm{~s}, 3 \mathrm{H}, \mathrm{C}-7^{\prime \prime} \mathrm{CH}_{3}\right)$, 1.19-1.40 (m, 2H, CH $\left., \mathrm{H}-2^{\prime \prime}, \mathrm{H}-5^{\prime \prime}\right), 1.81$ (d, 1H, J = 18.1 Hz, CH, H-4"), 1.80-1.92 (m, 1H, CH, H-5"), $1.95\left(\mathrm{t}, 1 \mathrm{H}, J=4.5 \mathrm{~Hz}, \mathrm{CH}, \mathrm{H}-4^{\prime \prime}\right), 2.16-2.34\left(\mathrm{~m}, 1 \mathrm{H}, \mathrm{CH}, \mathrm{H}-3^{\prime \prime}\right), 2.46\left(\mathrm{~d}, 1 \mathrm{H}, J=14.7 \mathrm{~Hz}, \mathrm{CH}, \mathrm{CH}_{2} \mathrm{SO}_{3} \mathrm{H}\right)$, 2.55-2.76 (m, 1H, CH, H-2") $2.93\left(\mathrm{~d}, 1 \mathrm{H}, J=14.7 \mathrm{~Hz}, \mathrm{CH}, \mathrm{CH}_{2} \mathrm{SO}_{3} \mathrm{H}\right), 3.73\left(\mathrm{~s}, 3 \mathrm{H}, \mathrm{OCH}_{3}\right), 4.10-4.32$ $\left(\mathrm{m}, 2 \mathrm{H}, \mathrm{CH}_{2}, \mathrm{H}-2\right), 4.87(\mathrm{dd}, 1 \mathrm{H}, J=7.3,5.5 \mathrm{~Hz}, \mathrm{CH}, \mathrm{H}-1), 6.20\left(\mathrm{t}, 1 \mathrm{H}, J=2.1 \mathrm{~Hz}, \mathrm{H}-4^{\prime}, \mathrm{Ar}\right), 6.87(\mathrm{~d}, 2 \mathrm{H}$, $J=8.7 \mathrm{~Hz}, \mathrm{H}-3 \mathrm{a}, \mathrm{H}-5 \mathrm{a}, \mathrm{Ar}), 7.22$ (d, 2H, $J=8.5 \mathrm{~Hz}, \mathrm{H}-2 \mathrm{a}, \mathrm{H}-6 \mathrm{a}, \mathrm{Ar}), 7.47$ (dd, $1 \mathrm{H}, J=1.9,0.7 \mathrm{~Hz}, \mathrm{H}-3^{\prime}$, 
$\mathrm{Ar}), 7.61\left(\mathrm{dd}, 1 \mathrm{H}, J=2.3,0.7 \mathrm{~Hz}, \mathrm{H}-5^{\prime}, \mathrm{Ar}\right) .{ }^{13} \mathrm{C} \mathrm{NMR}\left(\mathrm{DMSO}-d_{6}\right) \delta=19.5\left(\mathrm{C}-7^{\prime \prime} \mathrm{CH}_{3}\right), 20.0\left(\mathrm{C}-7^{\prime \prime} \mathrm{CH}_{3}\right)$, 24.2 (C-2"), $26.4\left(\mathrm{C}-5^{\prime \prime}\right), 42.1$ (C-3"), $42.2\left(\mathrm{C}-4^{\prime \prime}\right), 46.8\left(\mathrm{CH}_{2} \mathrm{SO}_{3} \mathrm{H}\right), 47.1$ (C-7"), 55.0 (OCH3), 58.1 (C-6"), 58.6 (C-2), 71.3 (C-1), 104.8 (C-4'), 113.5 (C-3a, C-5a), 127.2 (C-2a, C-6a), 130.9 (C-5'), 134.7 (C-1a), $138.1\left(\mathrm{C}-3^{\prime}\right), 158.5(\mathrm{C}-4 \mathrm{a}), 216.0(\mathrm{C}=\mathrm{O})$. ES ${ }^{+}$HRMS, $m / z=241.0946$ found (calculated for $\mathrm{C}_{12} \mathrm{H}_{14} \mathrm{~N}_{2} \mathrm{O}_{2} \mathrm{Na}$ $[\mathrm{M}-\mathrm{H}+\mathrm{Na}]^{+}$requires 241.0947).

$(+)-(1 R)-4 \mathbf{b} /(+)-(1 S)-C S A$ salt: Yield $=51 \%$. White powder, $\mathrm{Mp}=169-171{ }^{\circ} \mathrm{C} .\left[\alpha_{\mathrm{D}}\right]=+6.0(c 1.0, \mathrm{MeOH})$ and $>99 \%$ de (retention time $t_{R}=35.5 \mathrm{~min}$. using hexane $/ i-\mathrm{PrOH} 94: 6 \mathrm{v} / \mathrm{v}$ as eluent, flow rate $=$ $0.8 \mathrm{~mL} / \mathrm{min}$.). ${ }^{1} \mathrm{H}$ NMR (DMSO- $\left.d_{6}\right) \delta=0.75$ (s, 3H, C-7" $\left.\mathrm{CH}_{3}\right), 1.04$ (s, 3H, C-7"CH3), 1.17-1.42 (m, 2H, $\left.\mathrm{CH}_{2}, \mathrm{H}-2^{\prime \prime}, \mathrm{H}-5^{\prime \prime}\right), 1.81$ (d, 1H, J = 18.1 Hz, CH, H-4"), 1.78-1.93 (m, 1H, CH, H-5"), 1.95 (t, 1H, $\left.J=4.5 \mathrm{~Hz}, \mathrm{CH}, \mathrm{H}-4^{\prime \prime}\right), 2.25\left(\mathrm{dt}, 1 \mathrm{H}, J=18.0,4.0 \mathrm{~Hz}, \mathrm{CH}, \mathrm{H}-3^{\prime \prime}\right), 2.45\left(\mathrm{~d}, 1 \mathrm{H}, J=14.7 \mathrm{~Hz}, \mathrm{CH}, \mathrm{CH}_{2} \mathrm{SO} \mathrm{H}_{3} \mathrm{H}\right.$, 2.54-2.76 (m, 1H, CH, H-2"), $2.93\left(\mathrm{~d}, 1 \mathrm{H}, J=14.7 \mathrm{~Hz}, \mathrm{CH}, \mathrm{CH}_{2} \mathrm{SO}_{3} \mathrm{H}\right), 3.73\left(\mathrm{~s}, 3 \mathrm{H}, \mathrm{OCH}_{3}\right), 4.08-4.32$ $\left(\mathrm{m}, 2 \mathrm{H}, \mathrm{CH}_{2}, \mathrm{H}-2\right), 4.87(\mathrm{dd}, 1 \mathrm{H}, J=7.3,5.5 \mathrm{~Hz}, \mathrm{CH}, \mathrm{H}-1), 6.20\left(\mathrm{t}, 1 \mathrm{H}, J=2.1 \mathrm{~Hz}, \mathrm{H}-4^{\prime}, \mathrm{Ar}\right), 6.87(\mathrm{~d}$, $2 \mathrm{H}, J=8.7 \mathrm{~Hz}, \mathrm{H}-3 \mathrm{a}, \mathrm{H}-5 \mathrm{a}, \mathrm{Ar}), 7.22$ (d, 2H, J = 8.5 Hz, H-2a, H-6a, Ar), 7.43-7.41 (m, 1H, H-3' , Ar), $7.60\left(\mathrm{dd}, 1 \mathrm{H}, J=2.3,0.7 \mathrm{~Hz}, \mathrm{H}-5^{\prime}, \mathrm{Ar}\right) .{ }^{13} \mathrm{C}$ NMR (DMSO- $\left.d_{6}\right) \delta=19.5\left(\mathrm{C}-7^{\prime \prime} \mathrm{CH}_{3}\right), 20.0\left(\mathrm{C}-7^{\prime \prime} \mathrm{CH}_{3}\right)$, 24.2 (C-2"), $26.4\left(\mathrm{C}-5^{\prime \prime}\right), 42.1\left(\mathrm{C}-3^{\prime \prime}\right), 42.2\left(\mathrm{C}-4^{\prime \prime}\right), 46.8\left(\mathrm{CH}_{2} \mathrm{SO}_{3} \mathrm{H}\right), 47.1\left(\mathrm{C}-7^{\prime \prime}\right), 55.0\left(\mathrm{OCH}_{3}\right), 58.1\left(\mathrm{C}-6^{\prime \prime}\right)$, 58.6 (C-2), 71.3 (C-1), 104.8 (C-4'), 113.5 (C-3a, C-5a), 127.2 (C-2a, C-6a), 130.9 (C-5'), 134.7 (C-1a), 138.1 $\left(\mathrm{C}-3^{\prime}\right), 158.5(\mathrm{C}-4 \mathrm{a}), 216.0(\mathrm{C}=\mathrm{O})$. $\mathrm{ES}^{+}$HRMS, $m / z=241.0946$ found (calculated for $\mathrm{C}_{12} \mathrm{H}_{14} \mathrm{~N}_{2} \mathrm{O}_{2} \mathrm{Na}$ $[\mathrm{M}-\mathrm{H}+\mathrm{Na}]^{+}$requires 241.0947).

X-ray crystallographic data for (+)-(1R)-4b/(+)-(1S)-CSA salt: $\left(\mathrm{C}_{12} \mathrm{H}_{15} \mathrm{~N}_{2} \mathrm{O}_{2}, \mathrm{C}_{10} \mathrm{H}_{15} \mathrm{O}_{4} \mathrm{~S}\right)$; $M=450.54$. APEXII, Bruker-AXS diffractometer, Mo-K $\alpha$ radiation $(\lambda=0.71073 \AA), T=150(2) \mathrm{K}$; orthorhombic P 212121 (I.T.\#19), a = 7.2781(5), b=9.5344(5), c = 32.8134(19) $\AA, V=2277.0(2) \AA^{3} . Z$ $=4, d=1.314 \mathrm{~g} \cdot \mathrm{cm}^{-3}, \mu=0.182 \mathrm{~mm}^{-1}$. The structure was solved by direct methods using the SIR97 program [29], and then refined with full-matrix least-square methods based on F2 (SHELXL-97) [30] with the aid of the WINGX [31] program. All non-hydrogen atoms were refined with anisotropic atomic displacement parameters. Except oxygen- and nitrogen-linked hydrogen atoms that were introduced in the structural model through Fourier difference maps analysis, $\mathrm{H}$ atoms were finally included in their calculated positions. A final refinement on $F^{2}$ with 4854 unique intensities and 289 parameters converged at $\omega R\left(F^{2}\right)=0.0932(R(F)=0.0415)$ for 4347 observed reflections with $I$ $>2 \sigma(I)$. Crystallographic data for the structure of $(+)-(1 R)-4 \mathbf{b} /(+)-(1 S)-C S A$ salt in this paper have been deposited in the Cambridge Crystallographic Data Centre as supplementary publication number CCDC 1580544. Copies of the data can be obtained, free of charge, on application to CCDC, 12 Union Road, Cambridge CB21EZ, UK (fax: +44(0)-1223-336033 or e-mail: deposit@ccdc.cam.ac.uk).

(-)-(1S) 1-(4-Methoxyphenyl)-2-(1H-pyrazol-1-yl)ethan-1-ol (4b): Yield =38\%. White powder, Mp $=113-114{ }^{\circ} \mathrm{C} .\left[\alpha_{\mathrm{D}}\right]=-10.0(\mathrm{c} 1.0, \mathrm{MeOH})$ and $>99 \%$ de (retention time $t_{R}=52.6 \mathrm{~min}$. using hexane $/ i-\mathrm{PrOH} 96: 4 v / v$ as eluent, flow rate $=0.6 \mathrm{~mL} / \mathrm{min}$.). ${ }^{1} \mathrm{H}$ NMR (DMSO- $\left.d_{6}\right) \delta=3.73(\mathrm{~s}, 3 \mathrm{H}$, $\left.\mathrm{OCH}_{3}\right), 4.06-4.30\left(\mathrm{~m}, 2 \mathrm{H}, \mathrm{H}-2, \mathrm{CH}_{2}, \mathrm{H}-2\right), 4.87$ (q, $\left.1 \mathrm{H}, J=5.6 \mathrm{~Hz}, \mathrm{CH}, \mathrm{H}-1\right), 5.50$ (br d, $1 \mathrm{H}, J=4.5 \mathrm{~Hz}$, $\mathrm{OH}), 6.16\left(\mathrm{t}, 1 \mathrm{H}, J=2.0 \mathrm{~Hz}, \mathrm{H}-4^{\prime}, \mathrm{Ar}\right), 6.87(\mathrm{~d}, 2 \mathrm{H}, J=8.6 \mathrm{~Hz}, \mathrm{H}-3 \mathrm{a}, \mathrm{H}-5 \mathrm{a}, \mathrm{Ar}), 7.21(\mathrm{~d}, 2 \mathrm{H}, J=8.6 \mathrm{~Hz}$, $\mathrm{H}-2 \mathrm{a}, \mathrm{H}-6 \mathrm{a}, \mathrm{Ar}), 7.41$ (d, $\left.1 \mathrm{H}, J=1.8 \mathrm{~Hz}, \mathrm{H}-3^{\prime}, \mathrm{Ar}\right), 7.56$ (d, $\left.1 \mathrm{H}, J=2.2 \mathrm{~Hz}, \mathrm{H}-5^{\prime}, \mathrm{Ar}\right) .{ }^{13} \mathrm{C}$ NMR (DMSO- $d_{6}$ ) $\left.\delta=55.0\left(\mathrm{OCH}_{3}\right), 58.7(\mathrm{C}-2), 71.4(\mathrm{C}-1), 104.6\left(\mathrm{C}-4^{\prime}\right), 113.5(\mathrm{C}-3 \mathrm{a}, \mathrm{C}-5 \mathrm{a}), 127.2(\mathrm{C}-2 \mathrm{a}, \mathrm{C}-6 \mathrm{a}), 130.5 \mathrm{C}-5^{\prime}\right)$, 134.8 (C-1a), $138.4\left(\mathrm{C}-3^{\prime}\right), 158.5$ (C-4a). ES ${ }^{+}$HRMS, $m / z=241.0950$ found (calculated for $\mathrm{C}_{12} \mathrm{H}_{14} \mathrm{~N}_{2} \mathrm{O}_{2} \mathrm{Na}$ $[\mathrm{M}-\mathrm{H}+\mathrm{Na}]^{+}$requires 241.0953).

(+)-(1R) 1-(4-Methoxyphenyl)-2-(1H-pyrazol-1-yl)ethan-1-ol (4b): Yield $=41 \%$. White powder, $\mathrm{Mp}=$ $110-111^{\circ} \mathrm{C} .\left[\alpha_{\mathrm{D}}\right]=+10.0(c 1.0, \mathrm{MeOH})$ and $>99 \%$ de (retention time $t_{R}=63.5 \mathrm{~min}$. using hexane $/ i-\mathrm{PrOH}$ 96:4 $v / v$ as eluent, flow rate $=0.6 \mathrm{~mL} / \mathrm{min}$.). ${ }^{1} \mathrm{H}$ NMR $\left(\mathrm{DMSO}-d_{6}\right) \delta=3.73\left(\mathrm{~s}, 3 \mathrm{H}, \mathrm{OCH}_{3}\right), 4.09-4.29$ (m, 2H, H-2, $\left.\mathrm{CH}_{2}, \mathrm{H}-2\right), 4.87(\mathrm{q}, 1 \mathrm{H}, J=5.6 \mathrm{~Hz}, \mathrm{CH}, \mathrm{H}-1), 5.50(\mathrm{br} \mathrm{d}, 1 \mathrm{H}, J=4.5 \mathrm{~Hz}, \mathrm{OH}), 6.16(\mathrm{t}$, $\left.1 \mathrm{H}, J=2.0 \mathrm{~Hz}, \mathrm{H}-4^{\prime}, \mathrm{Ar}\right), 6.87(\mathrm{~d}, 2 \mathrm{H}, J=8.6 \mathrm{~Hz}, \mathrm{H}-3 \mathrm{a}, \mathrm{H}-5 \mathrm{a}, \mathrm{Ar}), 7.22(\mathrm{~d}, 2 \mathrm{H}, J=8.6 \mathrm{~Hz}, \mathrm{H}-2 \mathrm{a}, \mathrm{H}-6 \mathrm{a}$, Ar), $7.41\left(\mathrm{~d}, 1 \mathrm{H}, J=1.8 \mathrm{~Hz}, \mathrm{H}-3^{\prime}, \mathrm{Ar}\right), 7.56\left(\mathrm{~d}, 1 \mathrm{H}, J=2.2 \mathrm{~Hz}, \mathrm{H}-5^{\prime}, \mathrm{Ar}\right) .{ }^{13} \mathrm{C}$ NMR (DMSO- $\left.d_{6}\right) \delta$ $\left.=55.0\left(\mathrm{OCH}_{3}\right), 58.7(\mathrm{C}-2), 71.4(\mathrm{C}-1), 104.6\left(\mathrm{C}-4^{\prime}\right), 113.5(\mathrm{C}-3 \mathrm{a}, \mathrm{C}-5 \mathrm{a}), 127.2(\mathrm{C}-2 \mathrm{a}, \mathrm{C}-6 \mathrm{a}), 130.5 \mathrm{C}-5^{\prime}\right)$, 
134.8 (C-1a), 138.4 (C-3'), 158.5 (C-4a). ES ${ }^{+}$HRMS, $m / z=241.0950$ found (calculated for $\mathrm{C}_{12} \mathrm{H}_{14} \mathrm{~N}_{2} \mathrm{O}_{2} \mathrm{Na}$ $[\mathrm{M}-\mathrm{H}+\mathrm{Na}]^{+}$requires 241.0953).

\subsection{Biology Section}

\subsubsection{Reagents}

Dimethyl Sulfoxyde (DMSO-Ref D2438) and Thapsigargin (Tg-Ref: T9033) was purchased from Sigma-Aldrich. Corning ${ }^{\circledR}$ Cell-Tak $^{\mathrm{TM}}$ was purchased from Beckton Dickinson (Le Pont de Claix, France) (Ref: 354241). Fura-2 QBT ${ }^{\mathrm{TM}}$ Calcium Kit was purchased from Molecular Devices (Berkshire, UK) (Ref: R8198).

\subsubsection{Cell Culture}

The B-cell leukemia cell line PLP [32], which possesses the phenotypic characteristics of B-CLL cells [33], were maintained in RPMI-1640 containing $10 \%$ fetal calf serum and antibiotics (1\% of penicillin/streptomycin).

\subsubsection{Cytosolic $\mathrm{Ca}^{2+}$ Protocol}

For $\mathrm{Ca}^{2+}$ experiments, cells were seeded overnight into four wells plate (Nunc ${ }^{\mathrm{TM}}$ multidisches 4 wells flat-bottom-Ref: 176740 ) at $7 \times 10^{5}$ cells $/ \mathrm{mL}$ in $1 \mathrm{~mL}$ culture medium. Cell suspension was then transfered into $1.5 \mathrm{~mL}$ Microtube, pelleted, and loaded with Fura-2 acetoxymethyl ester (Fura-2 QBT ${ }^{\mathrm{TM}}$ ) fluorochrome according to the manufacturer's protocol. Cell suspension was dispensed onto Corning ${ }^{\circledR}$ Cell-Tak ${ }^{\mathrm{TM}}$ pre-coated 96 wells black clear bottom plate $(80 \mu \mathrm{L}$ per wells, density approximatively $5 \times 10^{4}$ cells per well) and incubated $1 \mathrm{~h}$ at $37^{\circ} \mathrm{C}, 5 \% \mathrm{CO}_{2}$. The Fura-2 QBT ${ }^{\mathrm{TM}}$ was aspirated and replaced by an equal volume of free $\mathrm{Ca}^{2+}$ Hepes-buffered solution containing (in $\mathrm{mM}$ ): $135 \mathrm{NaCl}$, $5 \mathrm{KCl}, 1 \mathrm{MgCl}_{2}, 1 \mathrm{EGTA}, 10$ Hepes, 10 glucose, $\mathrm{pH}$ adjusted at 7.45 with $\mathrm{NaOH}$. The tested compounds or DMSO control solvent solutions were added in wells $(4 \mu \mathrm{L})$ and incubated for $5 \mathrm{~min}$ at $37^{\circ} \mathrm{C}$ until evaluating calcium level on FlexStation $3^{\mathrm{TM}}$ Instrument.

\subsubsection{Measurement of Intracellular Calcium Levels}

Intracellular calcium levels were monitored by using the FlexStation $3^{\mathrm{TM}}$ (Molecular Devices, Berkshire, UK), a fluorescence plate reader measuring time-resolved intracellular $\mathrm{Ca}^{2+}$ concentration in a 96-well format with the dual-wavelength fluorescent calcium-sensitive dye Fura-2AM. Dual excitation wavelength capability permits ratiometric measurements of Fura-2AM peak emissions $(510 \mathrm{~nm})$ after excitations at 340 (bound to calcium) and $380 \mathrm{~nm}$ (unbound to $\mathrm{Ca}^{2+}$ ). Modifications in the 340/380 ratio reflect changes in intracellular-free $\mathrm{Ca}^{2+}$ concentrations. The FlexStation $3^{\mathrm{TM}}$ temperature was setting at $37^{\circ} \mathrm{C}$ during data acquisition. Thapsigargin $(2 \mu \mathrm{M})$ solution and Hepes-buffered solution with $\mathrm{Ca}^{2+}$ containing (in $\mathrm{mM}$ ): $135 \mathrm{NaCl}, 5 \mathrm{KCl}, 1 \mathrm{MgCl}_{2}, 2 \mathrm{CaCl}_{2}, 10$ Hepes, 10 glucose, $\mathrm{pH}$ adjusted at 7.45 with $\mathrm{NaOH}$ were added from a 96-well reservoir plate during Calcium Mobilization Assay running at 100 and 750 s, respectively. Experimental setup parameters were optimized (pipette heights, volumes and rate of additions) to minimize disturbance of the cells while ensuring rapid mixing. The data were stored for later analysis by using SoftmaxPro (Molecular Devices), Excel and Graph Pad Prism software (Graph Pad Software, La Jolla, CA, USA).

\subsubsection{Measurement of Store-Operated Calcium (SOC) Entry}

Intracellular $\mathrm{Ca}^{2+}$ stores were depleted with $2 \mu \mathrm{M}$ Thapsigargin an inhibitor of ER SERCA pumps under $\mathrm{Ca}^{2+}$-free conditions to determine the magnitude of intracellular $\mathrm{Ca}^{2+}$ release. Next, cells were returned to $\mathrm{Ca}^{2+}$-containing Hepes-buffered solution to measure SOCE. The magnitude of SOCE was estimated as the maximal values of normalized F340/F340 ratio following $\mathrm{Ca}^{2+}$ re-addition. 


\subsubsection{Calculation and Data Analysis}

Results are expressed as mean \pm SEM for each group. The number of experiments for each group is represented as $n$. Data analysis for functional assays was performed using Softmax Pro and Graph Pad Prism. (Graph Pad): $\mathrm{Ca}^{2+}$ concentration variations are estimated using the ratio of peak RFU at 340 and $380 \mathrm{~nm}$ (F340/F380) and for each measurement F340/F380 ratio values are normalized to the initial basal ratio before TG addition. Results are expressed in terms of percentage of response or percentage of inhibition compared to the maximum response on control condition. Inhibition is estimated as follow: \% Inhibition $=(100-\%$ response $)$. The $\mathrm{EC}_{50}$ values were estimated from the dose/response curves ( $\log \left(\right.$ inhibitor) vs. amplitude of the $\mathrm{Ca}^{2+}$ response) using a regression model $\left(\mathrm{Y}=\operatorname{Min}+(\operatorname{Max}-\operatorname{Min}) /\left(1+10^{\text {(LogIC50-X) } \times \text { HillSlope }}\right)\right.$ with variable slope (Prism5 GraphPad software). Min and Max are the minimal and maximal inhibition obtained. $\mathrm{EC}_{50}$ is defined as the concentration of drug required to obtain $50 \%$ of inhibitory effect.

Supplementary Materials: Supplementary materials can be found at http:/ /www.mdpi.com/1422-0067/19/3/ $856 /$ s1.

Acknowledgments: Camille D. Dago wishes to thank the Fondation Benianh International and the Ministère de l'Enseignement Supérieur et de la Recherche Scientifique de Côte d'Ivoire for their grants. Financial support of this program carried out under the French National Cancer Institute, Cancéropôle Grand Ouest, by contract "Ion Channel-Network", is gratefully acknowledged. The authors are grateful to the assistance of the staff of the CRMPO analytical chemistry core facility for HRMS analysis (CRMPO platform, ScanMAT UMS 2001 CNRS, Université de Rennes 1, Bât. 11A, Campus de Beaulieu, Rennes, France).

Author Contributions: Camille D. Dago realized the organic synthesis; Paul Le Maux performed the chiral HPLC analysis and taught this method of analysis to Camille D. Dago; Thierry Roisnel performed X-ray diffraction; Christophe Brigaudeau realized measurements of calcium in tumoral cells; Yves-Alain Bekro and Jean-Pierre Bazureau conceived and designed the chemical experiments; Olivier Mignen conceived and designed experiments in biology; Jean-Pierre Bazureau wrote the paper.

Conflicts of Interest: The authors declare no conflict of interest.

\section{References}

1. Bagal, S.K.; Brown, A.D.; Cox, P.J.; Omoto, K.; Owen, R.M.; Pryde, D.C.; Sidders, B.; Skerratt, S.E.; Stevens, E.B.; Storer, R.I.; et al. Ion Channels as Therapeutic Targets: A Drug Discovery Perspective. J. Med. Chem. 2013, 56, 593-624. [CrossRef] [PubMed]

2. Putney, J.W., Jr. A model for receptor-regulated calcium entry. Cell Calcium 1986, 7, 1-12. [CrossRef]

3. Putney, J.W., Jr. Capacitative calcium entry: From concept to molecules. Immunol. Rev. 2009, 231, 10-22. [CrossRef] [PubMed]

4. Prakriya, M.; Lewis, R.S. Store-Operated Calcium Channels. Physiol. Rev. 2015, 95, 1383-1436. [CrossRef] [PubMed]

5. Stathopulos, P.B.; Schindl, R.; Fahrner, M.; Zheng, L.; Gasmi-Seabrook, G.M.; Muik, M.; Romanin, C.; Ikura, M. STIM1/Orai1 coiled-coil interplay in the regulation of store-operated calcium entry. Nat. Commun. 2013, 4, 2963. [CrossRef] [PubMed]

6. Prevarskaya, N.; Skryma, R.; Shuba, Y. Calcium in tumour metastasis: New roles for known actors. Nat. Rev. Cancer 2011, 11, 609-618. [CrossRef] [PubMed]

7. Ritchie, M.F.; Zhou, C.; Houghton, P.J.; Soboloff, J. Wilms Tumor Suppressor 1 (WT1) and Early Growth Response 1 (EGR1) Are Regulators of STIM1 Expression. J. Biol. Chem. 2010, 285, 10591-10596. [CrossRef] [PubMed]

8. Yang, S.; Zhang, J.J.; Huang, X.Y. Orai1 and STIM1 are critical for breast tumor cell migration and metastasis. Cancer Cell 2009, 15, 124-134. [CrossRef] [PubMed]

9. Sabatino, A.D.; Rovedatti, L.; Kaur, R.; Spencer, J.P.; Brown, J.T.; Morisset, V.D.; Biancheri, P.; Leakey, N.A.B.; Wilde, J.I.; Scott, L.; et al. Targeting gut $\mathrm{T}$ cell $\mathrm{Ca}^{2+}$ release-activated $\mathrm{Ca}^{2+}$ channels inhibits $\mathrm{T}$ cell cytokine production and T-Box transcription factor T-Bet in inflammatory bowel disease. J. Immunol. 2009, 183, 3454-3462. [CrossRef] [PubMed] 
10. Varga-Szabo, D.; Braun, A.; Kleinschnitz, C.; Bender, M.; Pleines, I.; Pham, M.; Renné, T.; Stoll, G.; Nieswandt, B. The calcium sensor STIM1 is an essential mediator of arterial thrombosis and ischemic brain infarction. J. Exp. Med. 2008, 205, 1583-1591. [CrossRef] [PubMed]

11. Feske, S. Immunodeficiency due to defects in store-operated calcium entry. Ann. N. Y. Acad. Sci. 2011, 1238, 74-90. [CrossRef] [PubMed]

12. Jairaman, A.; Prakriya, M. Molecular pharmacology of store-operated CRAC channels. Channels 2013, 7, 402-414. [CrossRef] [PubMed]

13. Merritt, J.E.; Amstrong, W.P.; Benham, C.D.; Hallam, T.J.; Jacob, R.; Jaxa-Chamiec, A.; Leigh, B.K.; Mc Carthy, S.A.; Moores, K.E.; Rink, T.J. SK\&F 96365, a novel inhibitor of receptor-mediated calcium entry. Biochem. J. 1990, 271, 515-522. [CrossRef] [PubMed]

14. Sage, S.O.; Reast, R.; Rink, T.J. ADP evokes biphasic $\mathrm{Ca}^{2+}$ influx in fura-2-loaded human platelets. Evidence for $\mathrm{Ca}^{2+}$ entry regulated by the intracellular $\mathrm{Ca}^{2+}$ store. Biochem. J. 1990, 265, 675-680. [CrossRef] [PubMed]

15. Tian, C.; Du, L.; Zhou, Y.; Li, M. Store-operated CRAC channel inhibitors: Opportunities and challenges. Future Med. Chem. 2016, 8, 817-832. [CrossRef]

16. Roberts-Thomson, S.J.; Peters, A.A.; Grice, D.M.; Monteith, G.R. ORAI-mediated calcium entry: Mechanism and roles, diseases and pharmacology. Pharmacol. Ther. 2010, 127, 121-130. [CrossRef] [PubMed]

17. Chen, K.-H.; Liu, H.; Yang, L.; Jin, M.-W.; Li, G.-R. SKF-96365 strongly inhibits voltage-gated sodium current in rat ventricular myocytes. Pflugers Arch. Eur. J. Physiol. 2015, 467, 1227-1236. [CrossRef] [PubMed]

18. Jing, Z.; Sui, X.; Yao, J.; Xie, J.; Jiang, L.; Zhou, Y.; Pan, H.; Han, W. SKF-96365 activates cytoprotective autophagy to delay apoptosis in colorectal cancer cells through inhibition of the calcium/CaMKII $\gamma /$ AKTmediated pathway. Cancer Lett. 2016, 372, 226-238. [CrossRef] [PubMed]

19. Liua, H.; Yangb, L.; Chena, K.-H.; Sun, H.-Y.; Jin, M.-W.; Xiao, G.-S.; Wang, Y.; Li, G.-R. SKF-96365 blocks human ether-à-go-go-related gene potassium channels stably expressed in HEK 293 cells. Pharmacol. Res. 2016, 104, 61-69. [CrossRef] [PubMed]

20. Shin, D.H.; Nam, J.H.; Lee, E.S.; Zhang, Y.; Kim, S.J. Inhibition of $\mathrm{Ca}^{2+}$ release-activated Ca ${ }^{2+}$ channel (CRAC) by curcumin and caffeic acid phenethyl ester (CAPE) via electrophilic addition to a cysteine residue of Orai1. Biochem. Biophys. Res. Commun. 2012, 428, 56-61. [CrossRef] [PubMed]

21. Yonetoku, Y.; Kubota, H.; Miyazaki, Y.; Okamoto, Y.; Funatsu, M.; Yoshimura-Ishikawa, N.; Ishikawa, J.; Yoshino, T.; Takeuchi, M.; Ohta, M. Novel potent and selective $\mathrm{Ca}^{2+}$ release-activated $\mathrm{Ca}^{2+}$ (CRAC) channel inhibitors. Part 3: Synthesis and CRAC channel inhibitory activity of 4'-[(trifluoromethyl)pyrazol-1-yl]carboxanilides. Bioorg. Med. Chem. 2008, 16, 9457-9466. [CrossRef] [PubMed]

22. Sweeney, Z.K.; Minatti, A.; Button, D.C.; Patrick, S. Small-molecule inhibitors of Store-Operated Calcium Entry. ChemMedChem 2009, 4, 706-718. [CrossRef] [PubMed]

23. Derler, I.; Schindl, R.; Fritsch, R.; Heftberger, P.; Riedl, M.C.; Begg, M.; House, D.; Romanin, C. The action of selective CRAC channel blockers is affected by the Orai pore geometry. Cell Calcium 2013, 53, 139-151. [CrossRef] [PubMed]

24. Ng, S.W.; di Capite, J.; Singaravelu, K.; Parekh, A.B. Sustained Activation of the tyrosine kinase Syk by antigen in mast cells requires local $\mathrm{Ca}^{2+}$ influx through $\mathrm{Ca}^{2+}$ release-activated $\mathrm{Ca}^{2+}$ channels. J. Biol. Chem. 2008, 283, 31348-31355. [CrossRef] [PubMed]

25. Rahman, S.; Rahman, T. Unveiling some FDA-approved drugs as inhibitors of the store-operated $\mathrm{Ca}^{2+}$ entry $^{2}$ pathway. Nature 2017, 7, 12881. [CrossRef] [PubMed]

26. Dago, C.D.; Le Maux, P.; Roisnel, T.; Brigaudeau, C.; Bekro, Y.-A.; Mignen, O.; Bazureau, J.-P. Synthetic exploration on a novel series of pyrazole SKF-96365 analogues as potential Store-Operated Calcium Entry (SOCE) inhibitors for cancer. Presented at the 2nd International Caparica Christmas Congress on Translational Chemistry, Caparica, Portugal, 4-7 December 2017; Capelo, J.L., Lodeiro, C., Eds.; Abstract: O18A. p. 83.

27. Dago, C.D.; Messé, E.; Mignen, O.; Brigaudeau, C.; Bekro, Y.-A.; Bazureau, J.-P. A convenient four-step synthesis of 1-\{3-[3-(4-methoxy-phenyl)propoxy]-4-methoxyphenethyl\}-1H-imidazole hydrochloride as a probing tool for SOCE assays. Molbank 2016, 2016, M909. [CrossRef]

28. Brandt, J.; Gais, H.J. An efficient resolution of ( \pm )-S-methyl-S-phenylsulfoximine with (+)-10-camphorsulfonic acid by the method of half-quantities. Tetrahedron Asymmetry 1997, 8, 909-912. [CrossRef] 
29. Altomare, A.; Burla, M.C.; Camalli, M.; Cascarano, G.; Giacovazzo, C.; Guagliardi, A.; Moliterni, A.G.G.; Polidori, G.; Spagna, R. SIR97: A new tool for crystal structure determination and refinement. J. Appl. Crystallogr. 1999, 32, 115-119. [CrossRef]

30. Sheldrick, G.M. A short history of SHELX. Acta Crystallogr. 2008, A64, 112-122. [CrossRef] [PubMed]

31. Farrugia, L.J. WinGX and ORTEP for Windows: An update. J. Appl. Crystallogr. 2012, 45, 849-854. [CrossRef]

32. Renaudineau, Y.; Hillion, S.; Saraux, A.; Mageed, R.-A.; Youinou, P. An alternative exon 1 of the CD5 gene regulates CD5 expression in human B lymphocytes. Blood 2005, 15, 2781-2789. [CrossRef] [PubMed]

33. Garaud, S.; Taher, T.E.; Debant, M.; Burgos, M.; Melayah, S.; Berthou, C.; Parikh, K.; Pers, J.O.; Luque-Paz, D.; Chiocchia, G.; et al. CD5 expression promotes IL-10 production through activation of the MAPK/Erk pathway and upregulation of TRPC1 channels in B lymphocytes. Cell. Mol. Immun. 2016, 13, 1-13. [CrossRef] [PubMed]

(C) 2018 by the authors. Licensee MDPI, Basel, Switzerland. This article is an open access article distributed under the terms and conditions of the Creative Commons Attribution (CC BY) license (http://creativecommons.org/licenses/by/4.0/). 